\title{
Experimental Autoimmune Encephalomyelitis (EAE) as Animal Models of Multiple Sclerosis (MS)
}

\author{
Simon Glatigny ${ }^{1,2}$ and Estelle Bettelli ${ }^{1,2}$ \\ ${ }^{1}$ Immunology Program, Benaroya Research Institute, Seattle, Washington 98101 \\ ${ }^{2}$ Department of Immunology, University of Washington, Seattle, Washington 98109 \\ Correspondence: ebettelli@benaroyaresearch.org
}

Multiple sclerosis (MS) is a multifocal demyelinating disease of the central nervous system (CNS) leading to the progressive destruction of the myelin sheath surrounding axons. It can present with variable clinical and pathological manifestations, which might reflect the involvement of distinct pathogenic processes. Although the mechanisms leading to the development of the disease are not fully understood, numerous evidences indicate that MS is an autoimmune disease, the initiation and progression of which are dependent on an autoimmune response against myelin antigens. In addition, genetic susceptibility and environmental triggers likely contribute to the initiation of the disease. At this time, there is no cure for MS, but several disease-modifying therapies (DMTs) are available to control and slow down disease progression. A good number of these DMTs were identified and tested using animal models of MS referred to as experimental autoimmune encephalomyelitis (EAE). In this review, we will recapitulate the characteristics of EAE models and discuss how they help shed light on MS pathogenesis and help test new treatments for MS patients.

M ultiple sclerosis (MS) is a chronic, immunemediated, and demyelinating disease of the central nervous system (CNS), which affects more than 2.5 million people worldwide. It is characterized by inflammatory infiltrates, demyelinating plaques, and axonal damage (Lassmann et al. 2007). Although those features had been recognized early on, their origins were not understood. In the 1930s, Rivers and colleagues (Rivers et al. 1933) observed that vaccination of animals against rabies with a viral preparation contaminated with rabbit brain proteins, occasionally resulted in "paralytic accidents." Later, Rivers' group used normal rabbit brain extracts and correlated the disease-inducing capacity of the extract with its amount of myelin. This was the birth of experimental autoimmune (initially called allergic) encephalomyelitis (EAE). These experiments supported the hypothesis that MS had an autoimmune etiology and that a response against CNS antigens could trigger axonal damage and neurological deficits. This was later confirmed with the identification of different myelin antigens in various species and mouse strains, the generation of T-cell clones and lines recognizing specific epitopes in these antigens, and the use of these antigens to induce a paralytic and demyelinating disease in mice resembling MS. In this review, we highlight key features of several EAE models. We

Editors: Howard L. Weiner and Vijay K. Kuchroo

Additional Perspectives on Multiple Sclerosis available at www.perspectivesinmedicine.org

Copyright (C) 2018 Cold Spring Harbor Laboratory Press; all rights reserved; doi: 10.1101/cshperspect.a028977

Cite this article as Cold Spring Harb Perspect Med 2018;8:a028977 
describe how they were instrumental in identifying molecules and cell types involved in the pathogenesis and regulation of CNS autoimmunity and, furthermore, how they were indispensable in helping to test disease-modifying agents destined to modulate the course of MS.

\section{TOLERANCE AND ENCEPHALITOGENIC ANTIGENS}

The notion that MS is an autoimmune disorder is supported by several evidences. First, CNS plaques contain inflammatory infiltrates composed mainly of lymphocytes and myeloid cells. Oligoclonal antibodies are present in the cerebrospinal fluid (CSF) of many patients with MS. In addition, genome-wide association studies have shown association of MS with immunesystem-related gene variants, including human leukocyte antigen (HLA) molecules. Furthermore, immunotherapies are successfully used as disease-modifying therapies (DMTs) in MS (Sospedra and Martin 2005; Lassmann et al. 2007). One characteristic of autoimmune diseases is the failure of the immune system to maintain self-tolerance against tissue-specific antigens (TSAs). The purpose of central tolerance is to eliminate autoreactive $\mathrm{T}$ cells in the thymus and autoreactive $\mathrm{B}$ cells in the bone marrow to generate mature $\mathrm{T}$ - and $\mathrm{B}$-cell repertoires that recognize exogenous pathogens while displaying tolerance to self-antigens. Ectopic expression of many TSAs in medullary thymic epithelial cells allows for the elimination of many $\mathrm{T}$ cells specific for TSAs. However, the presence of autoreactive $\mathrm{T}$ cells on the periphery in MS patients and in healthy controls (HCs), as well as experiments performed in EAE, shows that central tolerance is not completely efficient (Walker and Abbas 2002). Indeed, several antigens have been investigated in multiple sclerosis as potential targets of the T-cell and B-cell responses, including myelin oligodendrocyte glycoprotein (MOG), proteolipid protein (PLP), myelin basic protein (MBP), myelin-associated glycoprotein (MAG), myelin-associated oligodendrocytic basic protein (MOBP), and others (Sospedra and Martin 2005). T cells specific for epitopes in these autoantigens have been detect- ed in MS patients, but also in healthy individuals (Ota et al. 1990; Liblau et al. 1991; Sun et al. 1991b; Chou et al. 1992; Zhang et al. 1994, 2004; Crawford et al. 2004; Berthelot et al. 2008; Huizinga et al. 2009; Raddassi et al. 2011; Elong Ngono et al. 2012). The use of these antigens to induce the development of a paralytic disease resembling MS has been seminal to establish their encephalitogenic potential. The use of these myelin-derived antigens emulsified in complete Freund's adjuvant (CFA) has led to the development of different experimental models of EAE. Furthermore, EAE can be actively induced by adoptive transfer of activated myelin-specific T cells into naïve recipient animals. The ability to induce EAE by transfer of myelinspecific $\mathrm{T}$ cells bolstered the idea that MS is a T-cell-mediated autoimmune disease.

\section{MBP-INDUCED EAE}

MBP represents $30 \%-40 \%$ of the CNS myelin proteins and $5 \%-15 \%$ of the peripheral myelin proteins (Lemke 1988; Huseby et al. 2001b; Perchellet et al. 2004). It was one of the first proteins to be purified from spinal cord homogenate and shown to induce EAE. Consistent with the antigen distribution, MBP-specific T cells also induce inflammation in peripheral nerve roots during EAE development (Pender et al. 1995). Two families of proteins, referred to as classic MBP and golli-MBP are transcribed from the MBP locus (Zelenika et al. 1993; Givogri et al. 2000). The first three exons in this locus are only expressed in golli-MBP proteins. Whereas golli-MBP isoforms are expressed in the CNS, thymus, and peripheral lymphoid tissues, promoters driving the expression of classic-MBP isoforms are primarily active in the central and peripheral nervous system (Goverman 2011). Furthermore, classical MBP isoforms are acetylated on the amino terminus. MBP was initially shown to induce EAE in SJL/J mice (Bernard and Carnegie 1975; Pettinelli et al. 1982; BenNun and Lando 1983) and PL/J mice (Fritz et al. 1983). Later, T-cell clones reactive against MBP peptide were shown to induce EAE in SJL/J mice (Zamvil et al. 1985a, 1986; Sakai et al. 1988). The disease course induced by MBP and its peptides 
is characterized by an acute paralytic episode from which the mice recover either partially or completely (Zamvil et al. 1985a). The study of shiverer mice, in which exons 7-11 of the MBP locus are deleted, has helped define how central tolerance shapes the peripheral MBP-specific Tcell repertoire. $\mathrm{T}$ cells specific for the $\mathrm{MBP}_{121-150}$ region are tolerized in mice that express MBP but $\mathrm{T}$ cells specific for $\mathrm{MBPAc}_{1-11}$ escape tolerance. It was further shown that both $\mathrm{MBP}_{125-135}$ and $\mathrm{MBP}_{136-146}$ peptides have high affinity, whereas $\mathrm{MBPAc}_{1-11}$ has low affinity for $\mathrm{I}-\mathrm{A}^{\mathrm{u}}$. This supports the paradigm that a large proportion of myelin-reactive $\mathrm{T}$ cells present in the peripheral repertoire escape central tolerance because they have low affinity with major histocompatibility complex (MHC) molecules.

\section{PLP-INDUCED EAE}

PLP is a major transmembrane protein of the CNS and is an essential component for the compaction of the CNS myelin (Ronchi et al. 2016). PLP was the first encephalitogenic myelin component to be identified (Waksman et al. 1954). However, the preparation of PLP was suspected to be contaminated with MBP and it is only in the late 1980s that purified PLP was shown to be encephalitogenic (Sobel et al. 1986). Active EAE can be induced with PLP or its immunodominant epitopes in susceptible strains (Tuohy et al. 1988, 1989; McRae et al. 1992). Immunization of

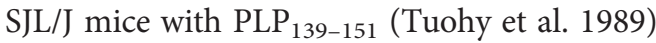
or by passive transfer of SJL-derived cluster-ofdifferentiation-4-positive $\left(\mathrm{CD}^{+}\right) \mathrm{PLP}_{139-151^{-}}$ specific T-cell line (Whitham et al. 1991) induces a relapsing remitting disease course (McRae et al. 1992). Furthermore, in SJL/J mice, PLP-specific T cells transfer a relapsing remitting EAE associated with "epitope spreading" (McRae et al. 1995). Interestingly, B10.S mice, which also carry the $\mathrm{H}-2^{\mathrm{s}}$ haplotype, are more resistant to PLP-induced EAE than SJL/J mice (Reddy et al. 2004). The PLP locus encodes for two different transcripts: the full-length PLP and a shorter isoform, DM-20 lacking epitope 139151. Only the splice variant DM-20 that lacks the encephalitogenic peptide $\mathrm{PLP}_{139-151}$ is expressed in the thymus and plays a role in mediating im- mune tolerance (Link et al. 1994; Anderson et al. 2000). Therefore, the PLP-induced disease in $\mathrm{SJL} / \mathrm{J}$ mice offers a unique and interesting relapsing remitting course but suffers from the lack of sufficient mice models of gene deletion.

\section{MOG-INDUCED EAE}

MOG is a very minor component $(0.01 \%-0.05 \%$ of membrane protein) that is expressed on the outer surface of CNS myelin (Iglesias et al. 2001). MOG has emerged as an important target in MS because MOG-reactive $\mathrm{T}$ cells seem to be more readily detected in MS patients than T cells reactive to PLP and MBP (Sun et al. 1991a; Xiao et al. 1991; Kerlero de Rosbo et al. 1993, 1997; Raddassi et al. 2011). Despite the fact that MOG expression has been detected in the thymus (Derbinski et al. 2001), there is no evidence for a strong process of central tolerance toward MOG-specific T cells (Bettelli et al. 2003; Delarasse et al. 2003; Pollinger et al. 2009). MOG and its peptides have been shown to induce EAE in several mouse strains, including C57BL/6, C3H.SW, SJL/J, PL/J, and nonobese diabetic (NOD) mice (Amor et al. 1994; Kerlero de Rosbo et al. 1995; Mendel et al. 1995, 1996; Encinas et al. 1999). C57BL/6 mice develop a chronic disease (Amor et al. 1994; Kerlero de Rosbo et al. 1995; Mendel et al. 1995, 1996; Encinas et al. 1999). In PL/J mice, MOG induces a non-classical chronic relapsing EAE (Amor et al. 1994). Interestingly, NOD mice immunized with $\mathrm{MOG}_{35-55}$ develop an initial acute episode of EAE followed by a secondary progressive EAE course (Encinas et al. 1999), which can serve to model the secondary progressive phase of disease observed in some MS patients (Degenhardt et al. 2009). After the demonstration that MOG and its peptide $\mathrm{MOG}_{35-55}$ could induce a potent and chronic form of EAE in otherwise resistant $\mathrm{H}-2^{\mathrm{b}}$ mice $(\mathrm{C} 57 \mathrm{BL} / 6$ and C3H.SW mice) (Amor et al. 1994; Kerlero de Rosbo et al. 1995; Mendel et al. 1995, 1996), this model became increasingly popular to study the role of specific molecules in the development and regulation of EAE because most gene-specific knockout $(\mathrm{KO})$ mice have been generated on the C57BL/6 background. 
S. Glatigny and E. Bettelli

\section{PATHOGENIC ROLE OF CD4 ${ }^{+}$T CELLS}

Genetic studies have highlighted the contribution of HLA-I and HLA-II molecules to disease susceptibility. The generation of $\mathrm{CD}^{+}$and $\mathrm{CD} 8^{+} \mathrm{T}$-cell lines and clones capable of transferring EAE after adoptive transfer has bolstered the idea that MS was a T-cell-mediated autoimmune disease. MBP-specific T cells were the first shown to induce EAE (Zamvil et al. 1985b). Shortly after, Mosmann and Coffman introduced the concept of division of labor among $\mathrm{CD} 4^{+} \mathrm{T}$ cells and the notion that $\mathrm{CD} 4^{+} \mathrm{T}$ cells can differentiate into different subsets of $\mathrm{T}$ cells (i.e., T helper cells 1 and 2 [Th1 and Th2]) depending on the surrounding cytokine environment (Mosmann and Coffman 1989). $\mathrm{CD}^{+}$ $\mathrm{T}$ cells secreting interferon $\gamma$ (IFN)- $\gamma^{+}$, interleukin (IL) $-17^{+}$, and/or granulocyte macrophage colony-stimulating factor $(\mathrm{GM}-\mathrm{CSF})^{+}$have been shown to induce robust EAE and to be increased in the blood and CSF of patients with MS (Brucklacher-Waldert et al. 2009; Montes et al. 2009; Hartmann et al. 2014). Interestingly, $\mathrm{CD}^{+} \mathrm{T}$ cells that are labeled with I- $\mathrm{A}^{\mathrm{b}} / \mathrm{MOG}$ tetramer and are more numerous in the CNS of mice with EAE preferentially express all three cytokines (Duhen et al. 2013). As previously mentioned, the differentiation of $\mathrm{CD} 4^{+} \mathrm{T}$ cells is governed by specific factors and transcriptional programs (Korn et al. 2009). In the presence of IFN- $\gamma$ and IL-12, signal transducers and activators of transcription (STAT) 1 and STAT4 are phosphorylated and promote the expression of T-bet and further differentiation of CD $4^{+} \mathrm{T}$ cells in Th1 cells (Glimcher and Murphy 2000). Th17 cells differentiate with the combined action of transforming growth factor $\beta$ (TGF- $\beta$ ) and IL-6 (Harrington et al. 2005; Bettelli et al. 2006b; Veldhoen et al. 2006) through Smad2/3 and STAT3, which promote RAR-related orphan receptor $\gamma \mathrm{t}(\mathrm{ROR} \gamma \mathrm{t})$ expression (Ivanov et al. 2006; Harris et al. 2007; Laurence et al. 2007; Mathur et al. 2007; Yang et al. 2007). Importantly, Th17 cells further require IL-23mediated signaling to become pathogenic (Bettelli et al. 2006b; Zhou et al. 2008; Awasthi et al. 2009; Jager et al. 2009; Lee et al. 2012). This is significant because TGF- $\beta$ also promotes the generation of nonpathogenic and regulatory $\mathrm{T}$ cells (Tregs) (Bettelli et al. 2006b; Zhou et al. 2008; Ghoreschi et al. 2010; Hirota et al. 2011; Lee et al. 2012). The generation of GM-CSFproducing $\mathrm{T}$ cells has initially been reported to be dependent on cytokines and factors common to Th17 cells such as IL-23 and IL-1b (Codarri et al. 2011; El-Behi et al. 2011). However, more recent studies show that their generation is dependent on STAT5 activation by IL-2 or IL-7 (Noster et al. 2014; Sheng et al. 2014). Whether other transcription factors are necessary for the differentiation of these cells remains unclear. Of note, $\mathrm{T}$ cells deficient in the basic helix-loophelix (bHLH) transcription factor differentially expressed in chondrocytes 1 (DEC1), also called Bhlhe40, produce limited amounts of GM-CSF and fail to promote EAE (Martinez-Llordella et al. 2013; Lin et al. 2014). Therefore, additional experiments are required to determine how unique $\mathrm{GM}^{-\mathrm{CSF}^{+}} \mathrm{T}$ cells are and what transcriptional profile defines them.

For many years, Th1 cells were assumed to be the main pathogenic cells in EAE and MS, whereas IL-4-producing Th2 cells were thought to inhibit them (Adorini et al. 1996). Indeed, increased clinical activity in MS correlated with the expression of IFN- $\gamma$ and IL-12 in the CNS and CSF (Gutcher and Becher 2007). Furthermore, MS was exacerbated by the administration of IFN- $\gamma$ (Panitch et al. 1987). In EAE, a key role for Th1 cells was also supported by CNS-infiltrating T cells secretion of IFN- $\gamma$, the detection of IL-12 p40 in inflammatory lesions, and the ability to induce disease by adoptive transfer of Th1 cells (Baron et al. 1993; Segal and Shevach 1996). Mice deficient in STAT4, IL-12 p40, and T-bet were found to be relatively resistant to the development of EAE (Chitnis et al. 2001; Cua et al. 2003; Bettelli et al. 2004). On the other hand, mice deficient for the main Th1 effector cytokine IFN- $\gamma$ and downstream signal transduction pathway STAT1 develop exacerbated EAE, raising questions concerning the pathogenic potential of Th1 cells (Bettelli et al. 2004). Furthermore, the demonstration that mice deficient for the IL-12 p35 subunit remain susceptible to EAE development, whereas mice deficient for the IL-23-specific p19 sub- 
unit were protected from EAE development and lacked a population of IL-17-producing T cells (Cua et al. 2003; Langrish et al. 2005), suggested that Th1 cells were not unique in their ability and perhaps not necessary to induce EAE. The importance of Th17 cells for the development of EAE was further shown by the resistance of ROR $\gamma$ t, IL-6, IL-23 p19, and IL-23R-deficient mice to EAE development and their lack of a stable Th17 population (Cua et al. 2003; Bettelli et al. 2006b; Ivanov et al. 2006; Awasthi et al. 2009). Increased numbers of IL-17 transcripts are detected in chronic MS lesions compared with either acute lesions or control tissue from individuals without CNS pathology (Lock et al. 2002). An increased frequency of IL- $17^{+} \mathrm{CD} 4^{+} \mathrm{T}$ cells has been detected in the blood and CSF of MS patients, particularly during relapses and in comparison to HCs (Montes et al. 2009). The transfer of Th17 cells induces severe EAE (Jager et al. 2009) and the analysis of an IL-17A cellfate-mapping reporter mouse showed that the majority of pathogenic $\mathrm{T}$ cells that infiltrate the CNS of mice with EAE originate from an IL-17A-producing precursor, which may or may not have maintained its IL-17 expression (Hirota et al. 2011). Consistent with these observations, $I l 17 a^{-1-}$ and $I l 17 f^{-/-}$mice are still susceptible to EAE, and IL-17 neutralization in vivo only partially modulates EAE severity (Hofstetter et al. 2005; Langrish et al. 2005; Park et al. 2005; Komiyama et al. 2006; Rohn et al. 2006; Haak et al. 2009). Therefore, the requirement for IL-17 in EAE is not the same as that for IL-23 because $I l 23^{-/-}$and IL-23R KO mice are completely resistant to EAE. Of note, whereas in vitro-generated Th17 cells express robust amounts of IL-17, in vivo-generated Th17 cells tend to lose IL-17 expression. The fact that Th17 cells tend to lose IL-17 secretion and acquire IFN- $\gamma$ production has promoted the idea that these cells were (more) plastic (than other Th subsets) and may depend on Th1specific transcription factors to be pathogenic (Gocke et al. 2007; Yang et al. 2009; Wang et al. 2014b). However, our group and others have shown that selective deletion of T-bet in $\mathrm{T}$ cells prevented the generation of Th1 cells but did not abrogate the generation of IL- $17^{+}$
IFN- $\gamma^{+}\left(\mathrm{GM}-\mathrm{CSF}^{+}\right) \mathrm{CD} 4^{+} \mathrm{T}$ cells and the development of EAE, challenging the notion that Th1 cells and the expression of T-bet in Th17 cells are crucial to the development of EAE (Duhen et al. 2013; Grifka-Walk et al. 2013; O'Connor et al. 2013). IL-17 ${ }^{+}$IFN- $\gamma^{+}$-producing T cells are frequently found in the target tissue during inflammatory disease such as rheumatoid arthritis and MS (Kebir et al. 2009; Boniface et al. 2010). The generation and role of these cells is, however, poorly characterized. Our laboratory has shown that IL-23 is critical to induce the production of IFN- $\gamma$ by Th17 cells (Duhen et al. 2013). Interestingly, IL-23 was also shown to induce the expression of GM-CSF in $\mathrm{CD}^{+} \mathrm{T}$ cells (Codarri et al. 2011; El-Behi et al. 2011). GM-CSF-deficient animals are resistant to the development of EAE (McQualter et al. 2001) and treatment of mice with GM-CSF antibody suppresses ongoing EAE (Codarri et al. 2011). The transfer of in vitro-generated Th cells into recipients has shown that Th1, Th17, and GM-CSF ${ }^{+}$Th cells each induce a disease characterized by specific immune cell infiltrates and specific patterns of lesions (Kroenke et al. 2008; Stromnes et al. 2008; Jager et al. 2009). For example, macrophages predominated in the infiltrates of Th1-cell-induced disease, whereas neutrophils were recruited by Th17 cells (Kroenke et al. 2008). GM-CSF produced by Th cells appears to act predominantly on $\mathrm{CCR}^{+} \mathrm{Ly} 6 \mathrm{C}^{+}$ monocytes and inflammatory monocyte-derived dendritic cells (moDCs) (Mildner et al. 2009; Ko et al. 2014; Croxford et al. 2015). We have shown that Th17 cells promote the development of ectopic lymphoid structures containing B cells (Peters et al. 2011). Similar cellular immune aggregates containing B cells have been reported in the meninges of patients with MS (Serafini et al. 2004; Magliozzi et al. 2007). The role of these ectopic lymphoid structures in the initiation and propagation of CNS autoimmunity remain to be defined.

\section{ROLE OF CD8 ${ }^{+}$T CELLS}

$\mathrm{CD}^{+} \mathrm{T}$ cells outnumber $\mathrm{CD} 4^{+} \mathrm{T}$ cells in brain lesions of MS patients (Babbe et al. 2000; Frischer et al. 2009) but their contribution to 
MS pathology and disease progression remain subject to debate. Some MBP-specific $\mathrm{CD}^{+} \mathrm{T}$ cells isolated from MS patients can kill oligodendrocytes (Jurewicz et al. 1998) but other CD8 ${ }^{+}$ Tregs capable of killing pathogenic $\mathrm{T}$ cells have been described (Karandikar et al. 2002; Tennakoon et al. 2006; Correale and Villa 2008; Lee et al. 2008; Baughman et al. 2011). In EAE, $\mathrm{CD}^{+}$myelin-reactive $\mathrm{T}$ cells can cause disease upon adoptive transfer in syngenic recipients (Huseby et al. 2001a; Sun et al. 2001; Friese et al. 2008), demonstrating that these cells can be pathogenic cells but may require the presence of $\mathrm{CD}^{+} \mathrm{T}$ cells (Leuenberger et al. 2013). On the other hand, $\mathrm{CD}^{+}$-deficient mice were shown to be resistant to the development of EAE, suggesting that $\mathrm{CD}^{+} \mathrm{T}$ cells could also regulate disease development (Koh et al. 1992; Jiang et al. 2001). In support of these latest functions, several populations of $\mathrm{CD}^{+} \mathrm{T}$ cells with capacity to regulate disease progression have also been identified in mice (Najafian et al. 2003; Lee et al. 2008; Chen et al. 2009). In summary, the role of $\mathrm{CD} 8^{+} \mathrm{T}$ cells in MS and EAE, similar to $\mathrm{CD} 4^{+} \mathrm{T}$ cells, is complex and warrants further analysis of different subsets in multiple models and their interactions with other immune cells.

Tregs are $\mathrm{CD}^{+}{ }^{+} \mathrm{T}$ cells capable of limiting effector T-cell populations. Tregs exert their immunosuppressive functions directly on effector $\mathrm{T}$ cells via secretion of inhibitory cytokines or contact-dependent interactions or indirectly by preventing antigen-presenting cell (APC) maturation (Sakaguchi and Sakaguchi 2005; Ziegler 2006; Josefowicz et al. 2012). They are therefore important to limit the development of EAE. Indeed, MBP-specific T-cell receptor (TCR) transgenic mice lacking endogenous Tregs when crossed with recombination-activating gene (RAG)-deficient mice developed enhanced EAE (Olivares-Villagomez et al. 1998; Hori et al. 2002). Furthermore, depletion of $\mathrm{CD}^{+}$ $\mathrm{CD}^{+} 5^{+} \mathrm{T}$ cells enriched in Tregs inhibited natural recovery from EAE (Kohm et al. 2002; Glatigny et al. 2015). In contrast, the transfer of Tregs to recipient mice reduced disease severity (Montero et al. 2004; Zhang et al. 2004; McGeachy et al. 2005; Gartner et al. 2006; Ste- phens et al. 2009). During active EAE, Tregs are believed to ameliorate disease progression through the control of effector T cells (Kohm et al. 2002; Zhang et al. 2004; Reddy et al. 2005; Sakaguchi 2005; Stephens et al. 2009; Koutrolos et al. 2014). The question of whether Th1, Th17, and ThGM-CSF-mediated EAE could be efficiently controlled by Tregs or required control by specialized Tregs has been raised (O'Connor et al. 2007; Chaudhry et al. 2009; Koch et al. 2009). In mice lacking integrin a4 in $\mathrm{T}$ cells, we have shown that the Th17-prone disease that developed could be controlled by Treg cells (Glatigny et al. 2011, 2015). Because Treg are most abundant in the CNS during the recovery phase of EAE, they are believed to play a major role during this phase of the disease, but their number and suppressive capacity might not be sufficient to limit effector $\mathrm{T}$ cells at the peak of EAE (Korn et al. 2007; O'Connor et al. 2007). In humans, there is still a controversy regarding a possible difference in circulating Treg numbers between MS patients and HCs (Putheti et al. 2004; Venken et al. 2006; Feger et al. 2007; Michel et al. 2008), but Tregs clearly have reduced functionality in MS patients (Viglietta et al. 2004; Haas et al. 2005; Venken et al. 2006; Cerosaletti et al. 2013). The precise factors leading to Treg dysfunction are, however, still being elucidated. In addition, effector $\mathrm{T}$ cells from MS patients are resistant to Treg-induced suppression (Schneider et al. 2008; Trinschek et al. 2013; Bhela et al. 2015). The tools (i.e., Foxp3-Cre [Rubtsov et al. 2008] and Foxp3KI [Bettelli et al. 2006b] lines), to study the functions of Tregs in EAE and the effects of specific pathways on the function of Tregs have significantly improved, but it remains to be determined whether the overwhelming inflammation created by most EAE immunization protocols is suitable to understand how these cells can control the development of EAE. Enhancing the function of human Treg is an area of intense investigation (Perdigoto et al. 2015), and further studies on the pathways that modulate the functions of Tregs in EAE and refining the experimental approaches to study them in EAE shall therefore provide valuable insights to limit MS progression. 


\section{ROLE OF B CELLS}

Intrathecally produced oligoclonal immunoglobulin $\mathrm{G}$ (IgG) bands are observed in a significant proportion of MS patients and have been historically used as a diagnosis for MS (Kabat et al. 1942; Karcher et al. 1959; Lowenthal et al. 1960). For a long time, this has fueled the hypothesis that $B$ cells were pathogenic in MS via the production of antibodies. Antibodies to myelin antigens have been identified in MS patients (Cross et al. 2001; Berger et al. 2003). However, the beneficial effect of B-cell-depletion therapy in MS patients (Bar-Or et al. 2008; Hauser et al. 2008; Kappos et al. 2011; Sorensen et al. 2014) suggests that $B$ cells have a pathogenic role in MS through other mechanisms than antibody production because plasmablasts are not depleted. In mice, the importance of $B$ cells for disease pathogenesis has been shown by studying Bcell-deficient mice and mice carrying the heavy chain of a MOG-specific antibody knocked in the Ig heavy chain locus. Immunization of mice with recombinant MOG generates MOG-specific antibodies that aggravate EAE and promote demyelination (Smith et al. 2005). However, anti-MOG antibodies are not sufficient to initiate EAE development and need to be injected with myelin-specific $\mathrm{T}$ cells to induce disease (Linington et al. 1988). In support of that, mice carrying the heavy chain of the anti$\mathrm{MOG}_{8-18} \mathrm{C} 5$ antibody paired with endogenous light chains do not develop spontaneous EAE (Litzenburger et al. 1998). Therefore, antibodies might not be the only and dominant mechanism by which $B$ cells show their pathogenic activity in CNS autoimmunity. B cells have the capacity to present antigen, provide costimulatory signals to $\mathrm{T}$ cells, and secrete cytokines that can have a profound effect on pathogenic $\mathrm{T}$ cells. These specialized functions can either promote the pathogenic or the regulatory potential of $B$ cells. B cells represent an important source of cytokines, which can shape the T-cell immune response. For example, mice with IL-6 deficiency in B cells develop less severe disease (Molnarfi et al. 2013). The mode and timing of activation likely plays an important role in shaping the functions of $\mathrm{B}$ cells during $\mathrm{CNS}$ autoim- munity. Indeed, B-cell-deficient mice are susceptible to $\mathrm{MOG}_{35-55}$-induced EAE but failed to develop EAE if immunized with MOG protein (Lyons et al. 1999; Fillatreau et al. 2002). In addition, B-cell depletion with anti-CD20 antibody treatment prevented or reversed established recombinant MOG (rMOG)-induced EAE but exacerbated $\mathrm{MOG}_{35-55}$ EAE (Weber et al. 2010). Furthermore, mice with selective deficiency of MHC II on B cells failed to develop clinical disease (Molnarfi et al. 2013). This indicates that B cells play an important role for the presentation of whole myelin antigen to $\mathrm{CD}^{+} \mathrm{T}$ cells and the generation of pathogenic $T$ cells of the same specificity. The importance of B cells as APCs and a source of soluble mediators has been further shown in spontaneous mouse models of EAE (Bettelli et al. 2006a; Krishnamoorthy et al. 2006; Pollinger et al. 2009). Indeed, whereas a small frequency of MOG-specific TCR transgenic mice (2D2) develop spontaneous EAE, the provision of MOGspecific $B$ cells, when these mice are crossed with Th mice, increased their incidence of spontaneous EAE to 60\% (Bettelli et al. 2006a; Krishnamoorthy et al. 2006). MOG-specific B cells presented the antigen to $T$ cells more efficiently than other APCs and therefore led to the development of spontaneous EAE (Bettelli et al. 2006a; Krishnamoorthy et al. 2006). In contrast to this proinflammatory role, B cells can also play a regulatory role in the progression of CNS autoimmunity. Regulatory B cells (Bregs) have been shown to promote EAE recovery through the secretion of IL-10 and/or IL-35 (Fillatreau et al. 2002; Matsumoto et al. 2014; Shen et al. 2014; Wang et al. 2014a). Additional pathways may, however, promote regulatory proprieties in B cells and negatively regulate the immune response. Enhancement of Treg proliferation by Breg through a glucocorticoidinduced necrosis factor receptor ligand-glucocorticoid-induced necrosis factor receptor (GITRL-GITR) interaction has been proposed as an IL-10-independent mechanism by which $B$ cells can suppress the development of EAE (Ray et al. 2012). In another report, Breg cells were shown to exercise their suppressive function via programmed death ligand 1 (PD-L1). 
Interestingly, these $\mathrm{PD}-\mathrm{L} 1^{\text {hi }}$ Bregs were, in contrast to other B cells, refractory to B-cell-depletion therapy with $\alpha \mathrm{CD} 20$ antibody treatment (Khan et al. 2015). We have determined that the expression of integrin $\alpha 4$ (Itga4) on B cells was important for the presence and activity of Bregs in secondary lymphoid organs and their capacity to regulate pathogenic $\mathrm{T}$ cells and EAE progression (Glatigny et al. 2016). In summary, much still needs to be learned regarding different B-cell subsets and their functions in CNS autoimmunity progression and regulation to guaranty effectiveness of current DMTtargeting B cells without increasing the risk of side effects.

\section{SPONTANEOUS EAE MODELS}

Actively induced EAE rely on the priming of myelin-specific $\mathrm{T}$ cells with myelin antigen or peptide emulsified in CFA and, depending on the mouse strain, the injection of pertussis toxin. Although this mode of EAE induction has been useful in defining the mechanisms regulating pathogenic T-cell responses and disease progression, they rely on the artificial stimulation of $\mathrm{T}$ cells and they are not well suited for studying the initial phases of CNS autoimmune development. The generation of transgenic mice expressing myelin-specific $\mathrm{T}$ - or B-cell receptors have addressed some of these issues and provided models of spontaneous CNS autoimmune development with diverse incidence, clinical, and pathological patterns.

In the early 1990s, two independent groups developed transgenic mice for a TCR specific for the dominant epitope $A c_{1-11}$ and $A c_{1-9}$ of MBP restricted by $\mathrm{H}^{\mathrm{u}}{ }^{\mathrm{u}}$ (B10.PL and $\mathrm{PL} / \mathrm{J}$ ) (Goverman et al. 1993; Lafaille et al. 1994). Both of these mice did not develop EAE or developed spontaneous EAE at very low incidence in conventional housing conditions. However, $100 \%$ of mice develop spontaneous EAE when crossed with RAG-deficient animals and could be protected from disease development by transfer of purified $\mathrm{CD}^{+} \mathrm{T}$ cells (containing Tregs) from normal mice (Olivares-Villagomez et al. 1998). These findings were critical to show the importance of Tregs in regulating CNS autoimmune disease development (OlivaresVillagomez et al. 1998).

Soon after, the Kuchroo laboratory generated several other TCR transgenic mice that established novel spontaneous EAE models. Indeed, a number of $\mathrm{H}-2^{\mathrm{s}}$-restricted TCR transgenic mice were developed (Waldner et al. 2000; Munder et al. 2002). Interestingly, $\mathrm{PLP}_{139-151 \text {-specific }}$ TCR transgenic mice (5B6) developed fulminant aggressive spontaneous EAE at a high frequency on the SJL/J background (Waldner et al. 2000) but the rate of spontaneous EAE dropped dramatically when crossed with B10.S (Waldner et al. 2000). The resistance to spontaneous EAE development could be reversed after exposure to microbial antigens such as Toll-like receptor 4 (TLR4) and TLR9 ligands (Waldner et al. 2004). Similarly, TCR transgenic mice specific for $\mathrm{MOG}_{92-106}$ develop spontaneous $\mathrm{EAE}$ on the SJL/J background but not on the B10S background because of the sequestration of pathogenic Th17 cells in the intestine (Berer et al. 2014). These findings suggest that in a nonpermissive genetic environment, environmental stimuli can promote EAE development.

Later, we developed a $\mathrm{MOG}_{35-55}$-specific TCR transgenic mouse, called 2D2, on the C57BL/6 background (Bettelli et al. 2003). Only a low percentage $(\sim 4 \%)$ of $2 \mathrm{D} 2$ transgenic animals developed spontaneous EAE but more than $30 \%$ of mice developed spontaneous optic neuritis without EAE. Optic neuritis represents one of the first clinical presentations of CNS autoimmunity in a significant proportion of MS patients before any manifestation of MS (Ghezzi et al. 1999; Soderstrom 2001). However, the underlying immunological basis for different clinical forms of MS and its association with optic neuritis are not well defined. The predilection of 2D2 mice to develop optic neuritis was associated with higher expression of MOG in the optic nerve than in the spinal cord. These results show that clinical manifestations of CNS autoimmune disease can be modulated by the expression of the autoantigen in different parts of the CNS. When 2D2 were crossed with mice expressing MOG-specific B cells (Th mice), $>60 \%$ of $2 \mathrm{D} 2$ Th mice displayed spontaneous EAE (Bettelli et al. 2004, 2006a; Krishnamoor- 
thy et al. 2006). The disease started between 4 and 8 weeks of age and was characterized by the presence of inflammatory lesions in the spinal cord and optic nerve as well as ectopic follicle-like structures in the CNS (Bettelli et al. 2006a). Very similarly, TCR transgenic mice (1C6) specific for $\mathrm{MOG}_{35-55}$ on the NOD background only developed spontaneous optic neuritis but had full-blown EAE when crossed with Th mice (Anderson et al. 2012). Although the previously mentioned models provided MOG-specific B cells, the development of spon-

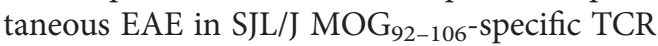
transgenic mice required $B$ cells and, more specifically, the expansion of myelin-specific B cells from the endogenous repertoire (Pollinger et al. 2009). These models highlighted the importance of B cells as highly efficient APCs of cognate antigen.

The number of $\mathrm{CD}^{+}{ }^{+} \mathrm{TCR}$ transgenic mice that developed spontaneous EAE is more limited. MHC class I-restricted MBP TCR transgenic mice have been generated and did not show spontaneous EAE symptoms (Berer et al. 2014) unless infected (Ji et al. 2010). In contrast, TCR transgenic mice specific for glial fibrillary acidic protein (GFAP) $264-272$ develop spontaneous relapsing remitting EAE characterized by both classical and atypical signs. Interestingly, there was also both gray and white matter pathology observed in the brain of these mice with disease (Sasaki et al. 2014).

Humanized TCR transgenic mice carrying TCR derived from myelin-specific clones and their associated HLA restriction molecules have also been generated to establish the role of specific human $\mathrm{T}$-cell responses in the pathogenesis of CNS autoimmunity. Human $\mathrm{MBP}_{84-102^{-}}$ specific TCR and HLA-DR15 double transgenic mice developed EAE at a low frequency, which was increased on the RAG KO background (Madsen et al. 1999; Ellmerich et al. 2005; Gregersen et al. 2006; Quandt et al. 2012). Consistent with the disease-promoting role of HLA-A3 and the disease-regulating role of HLA-A2, $\mathrm{PLP}_{45-53}$-specific $\mathrm{CD}^{+}$TCR and HLA-A3 transgenic mice developed disease initiated by $\mathrm{CD}^{+} \mathrm{T}$ cells and propagated by $\mathrm{CD} 4^{+} \mathrm{T}$ cells while HLA-A2 was protective (Friese et al. 2008).
Therefore, the analysis of these various TCR transgenic mice has been extremely useful to determine how autoreactive T cells are activated and cause CNS autoimmunity. The combination of these spontaneous EAE models and mice with conditional deletion or expression of specific genes in discrete cell types will without doubt further clarify the mechanisms of disease initiation and regulation.

\section{ROLE OF EAE IN THE DEVELOPMENT OF MS DMT}

In addition to contributing to our understanding of the mechanisms of CNS autoimmunity, EAE has been extremely valuable in determining the efficacy of DMTs. Several DMTs are now approved for the treatment of patients with MS and most of them have previously been tested in EAE: three formulations of IFN- $\beta$, glatiramer acetate (GA), mitoxantrone, natalizumab, and three oral drugs (i.e., fingolimod, teriflunomide, and dimethyl fumarate [DMF]).

In 1982, type I IFN was found to reduce the severity of EAE (Abreu 1982). IFN- $\beta$ was then approved in 1993 for the treatment of MS. Although IFN- $\beta$ is efficacious in a majority of patients and has limited side effects, almost $30 \%$ of MS patients do not respond to the treatment (Comabella et al. 2009a,b). Despite decades of research, it is still unclear how type I IFN shows its therapeutic effect in a majority of MS patients and why it remains inefficacious in others. In mice, IFN- $\beta$ was proposed to be beneficial in Th1-mediated disease but worsened EAE signs in Th17-mediated disease (Axtell et al. 2010). However, it is unclear that a similar dichotomy exists in MS patients treated with IFN- $\beta$ (Bushnell et al. 2012). Further defining the cell-typespecific effects of IFN- $\beta$ during the course of EAE could improve efficacy.

GA is a random copolymer of four amino acids that was originally designed as a synthetic MBP mimic for use in the induction of EAE (Teitelbaum et al. 1971, 1974). However, GA failed to induce EAE and when administered with MBP, suppressed EAE development (Teitelbaum et al. 1971). GA has shown efficacy in the treatment of relapsing remitting MS (RRMS) 
and limits disease relapse by $30 \%$ (Johnson et al. 1995). GA is believed to interfere with antigen presentation, induce a cytokine shift toward immunoregulatory profile, and induce immune tolerance (Arnon and Aharoni 2009).

Natalizumab, a monoclonal antibody against the $\alpha 4 \beta 1$ integrin or Very Late Antigen 4 (VLA4 ), was developed and used as a DMT (Miller et al. 2003) after the demonstration in the early 1990s that VLA-4 was required for the entry of T cells into the CNS and could limit EAE progression (Yednock et al. 1992). Natalizumab is very efficacious in limiting disease relapse and lesion development but has been associated with a high risk of developing progressive multifocal leukoencephalopathy (PML) in individuals carrying antibodies to the John Cunningham (JC) virus (Schwab et al. 2016). Although blocking or neutralizing VLA-4 was originally thought to uniformly block the entry of immune cells in the CNS, our group and others have shown, through the use of mice with T-cell-specific deletion of Itga4, that this integrin is selectively required for the entry of Th1 cells but dispensable for the entrance of Th17 and Treg cells in the CNS (Glatigny et al. 2011, 2015; Rothhammer et al. 2011). Furthermore, in the absence of Itga4 expression on $\mathrm{T}$ cells, EAE severity was significantly decreased and controlled by Treg cells, which could enter the CNS during CNS autoimmunity independently of Itga4 (Glatigny et al. 2015). Therefore, our data suggest that a differential infiltration of immune cells in the CNS could account for the diminished immune surveillance of the CNS observed in MS patients treated with natalizumab and possible complications associated with the treatment.

Fingolimod was the first oral therapy approved for RRMS. It antagonizes the function of sphingosine 1-phosphate receptors (S1PRs). S1PRs are a family composed of five members, with S1P1 being widely expressed on immune cells (Brinkmann 2007). S1P1 is critical to sense the gradient of $\mathrm{S} 1 \mathrm{P}$ present in the microenvironment and to regulate egress of lymphocytes from the secondary lymphoid organs (Matloubian et al. 2004). Injection of fingolimod in SJL mice significantly reduced EAE severity (Webb et al. 2004). Following clinical trials showing a relative reduction in the relapse rate in fingolimod-treated patients, it was approved by the Food and Drug Administration (FDA) as an oral drug for the treatment of RRMS. Inhibition of T-cell infiltration into the CNS by sequestration of $\mathrm{T}$ cells in secondary lymphoid tissue (Kataoka et al. 2005) and a beneficial effect on glial cells (Balatoni et al. 2007; Foster et al. 2007, 2009) have been proposed as the mechanisms of fingolimod efficacy. Because there is already evidence that fingolimod does not uniformly and equally block the egress of all Th cell subsets (Song et al. 2014), determining its effect on Tregs could provide novel insight into possible longterm effects of fingolimod use in MS patients.

Teriflunomide is the active metabolite of the parent drug, leflunomide. It has the ability to inhibit pyrimidine synthesis in rapidly proliferating cells (Oh and O'Connor 2014). DMF is a fumaric acid ester (FAE) capable of activating the antioxidative transcription factor nuclear factor (erythroid-derived 2)-like 2 (Nrf2) pathway (Linker et al. 2011; Brennan et al. 2015). The precise mechanisms by which teriflunomide exerts its beneficial effects in MS are, however, incompletely understood and it may have additional immunological effects. It has showed efficacy in the Dark Agouti (DA) rat EAE model, which mimics the inflammatory features of RRMS (Merrill et al. 2009; Ringheim et al. 2013). However, DMF protected wild type (WT) and Nrf2 KO mice equally well from the development of clinical and histologic EAE (Schulze-Topphoff et al. 2016). Another report showed that DMF inhibited expression of Itga4 on circulating $\mathrm{T}$ and B cells (Kihara et al. 2015). Therefore, the anti-inflammatory activity of DMF in treatment of MS patients may occur through alternative pathways, independent of Nrf2.

Therefore, additional experiments are required to further define the mode of action of recently developed DMTs. In addition, once a DMT has been used in the clinic for some time, there is often little incentive or support to better define the mechanisms of its efficacy and side effects. However, this is probably a strategic mistake because science and tools have considerably improved since the initial proof-of-concept experiments performed before FDA DMT 
approval. Much is to be learned from the immunology associated with therapeutic efficacy, refractoriness, and side effects of current DMTs to better design and test future and improved treatments for MS.

\section{CONCLUSIONS}

In conclusion, the pathophysiology of MS is complex, involving different cell types, myelinassociated autoantigens, and modifying genetic and environmental factors. It is, therefore, unrealistic to expect one animal model to recapitulate all the characteristics of MS pathophysiology and to encompass the genetic diversity of the patient population and the range of environmental elements that might influence disease initiation and progression. Instead, each EAE model mimics a particular aspect of MS and the diversity of the models provide a significant strength. Importantly, the aforementioned EAE models have proven extremely useful to discover and test the efficacy of DMTs. Spontaneous EAE models especially hold great promise as a system for studying MS pathogenesis and will be extremely useful to test compounds that can ameliorate or prevent disease. In addition, gene-targeting advances in mice now allow us to conditionally express or delete a gene of interest in a cell-type-specific manner. This greatly accelerates the process of identifying mechanisms behind the development, maintenance, and regulation of the pathogenic immune response during CNS autoimmunity. However, additional models are needed to mimic progressive MS and the progressive tissue damage that occurs in primary progressive MS.

\section{ACKNOWLEDGMENTS}

We thank Dr. Vijay K. Kuchroo for his seminal contributions to the field of EAE and for training opportunities.

\section{REFERENCES}

Abreu SL. 1982. Suppression of experimental allergic encephalomyelitis by interferon. Immunol Commun 11: 1-7.
Adorini L, Guery JC, Trembleau S. 1996. Manipulation of the Th1/Th2 cell balance: An approach to treat human autoimmune diseases? Autoimmunity 23: 53-68.

Amor S, Groome N, Linington C, Morris MM, Dornmair K, Gardinier MV, Matthieu JM, Baker D. 1994. Identification of epitopes of myelin oligodendrocyte glycoprotein for the induction of experimental allergic encephalomyelitis in SJL and Biozzi AB/H mice. J Immunol 153: 43494356.

Anderson AC, Nicholson LB, Legge KL, Turchin V, Zaghouani H, Kuchroo VK. 2000. High frequency of autoreactive myelin proteolipid protein-specific $\mathrm{T}$ cells in the periphery of naïve mice: Mechanisms of selection of the self-reactive repertoire. J Exp Med 191: 761-770.

Anderson AC, Chandwaskar R, Lee DH, Sullivan JM, Solomon A, Rodriguez-Manzanet R, Greve B, Sobel RA, Kuchroo VK. 2012. A transgenic model of central nervous system autoimmunity mediated by $\mathrm{CD} 4^{+}$and $\mathrm{CD} 8^{+} \mathrm{T}$ and B cells. J Immunol 188: 2084-2092.

Arnon R, Aharoni R. 2009. Neuroprotection and neurogeneration in MS and its animal model EAE effected by glatiramer acetate. J Neural Transm (Vienna) 116: 1443-1449.

Awasthi A, Riol-Blanco L, Jager A, Korn T, Pot C, Galileos G, Bettelli E, Kuchroo VK, Oukka M. 2009. Cutting edge: IL-23 receptor GFP reporter mice reveal distinct populations of IL-17-producing cells. J Immunol 182: 59045908.

Axtell RC, de Jong BA, Boniface K, van der Voort LF, Bhat R, De Sarno P, Naves R, Han M, Zhong F, Castellanos JG, et al. 2010. T helper type 1 and 17 cells determine efficacy of interferon- $\beta$ in multiple sclerosis and experimental encephalomyelitis. Nat Med 16: 406-412.

Babbe H, Roers A, Waisman A, Lassmann H, Goebels N, Hohlfeld R, Friese M, Schroder R, Deckert M, Schmidt S, et al. 2000. Clonal expansions of $\mathrm{CD} 8^{+} \mathrm{T}$ cells dominate the $\mathrm{T}$ cell infiltrate in active multiple sclerosis lesions as shown by micromanipulation and single cell polymerase chain reaction. J Exp Med 192: 393-404.

Balatoni B, Storch MK, Swoboda EM, Schonborn V, Koziel A, Lambrou GN, Hiestand PC, Weissert R, Foster CA. 2007. FTY720 sustains and restores neuronal function in the DA rat model of MOG-induced experimental autoimmune encephalomyelitis. Brain Res Bull 74:307-316.

Baron JL, Madri JA, Ruddle NH, Hashim G, Janeway CA Jr. 1993. Surface expression of $\alpha 4$ integrin by CD4 T cells is required for their entry into brain parenchyma. J Exp Med 177: 57-68.

Bar-Or A, Calabresi PA, Arnold D, Markowitz C, Shafer S, Kasper LH, Waubant E, Gazda S, Fox RJ, Panzara M, et al. 2008. Rituximab in relapsing-remitting multiple sclerosis: A 72-week, open-label, phase I trial. Ann Neurol 63: 395400.

Baughman EJ, Mendoza JP, Ortega SB, Ayers CL, Greenberg BM, Frohman EM, Karandikar NJ. 2011. Neuroantigenspecific $\mathrm{CD}^{+}$regulatory T-cell function is deficient during acute exacerbation of multiple sclerosis. J Autoimmun 36: $115-124$.

Ben-Nun A, Lando Z. 1983. Detection of autoimmune cells proliferating to myelin basic protein and selection of $\mathrm{T}$ cell lines that mediate experimental autoimmune encephalomyelitis (EAE) in mice. J Immunol 130: 1205-1209. 
Berer K, Boziki M, Krishnamoorthy G. 2014. Selective accumulation of pro-inflammatory $\mathrm{T}$ cells in the intestine contributes to the resistance to autoimmune demyelinating disease. PLoS ONE 9: e87876.

Berger T, Rubner P, Schautzer F, Egg R, Ulmer H, Mayringer I, Dilitz E, Deisenhammer F, Reindl M. 2003. Antimyelin antibodies as a predictor of clinically definite multiple sclerosis after a first demyelinating event. $N$ Engl J Med 349: 139-145.

Bernard CC, Carnegie PR. 1975. Experimental autoimmune encephalomyelitis in mice: Immunologic response to mouse spinal cord and myelin basic proteins. J Immunol 114: $1537-1540$.

Berthelot L, Laplaud DA, Pettre S, Ballet C, Michel L, Hillion S, Braudeau C, Connan F, Lefrere F, Wiertlewski S, et al. 2008. Blood $\mathrm{CD}^{+} \mathrm{T}$ cell responses against myelin determinants in multiple sclerosis and healthy individuals. Eur J Immunol 38: 1889-1899.

Bettelli E, Pagany M, Weiner HL, Linington C, Sobel RA, Kuchroo VK. 2003. Myelin oligodendrocyte glycoprotein-specific $\mathrm{T}$ cell receptor transgenic mice develop spontaneous autoimmune optic neuritis. J Exp Med 197: 1073-1081.

Bettelli E, Sullivan B, Szabo SJ, Sobel RA, Glimcher LH, Kuchroo VK. 2004. Loss of T-bet, but not STAT1, prevents the development of experimental autoimmune encephalomyelitis. J Exp Med 200: 79-87.

Bettelli E, Baeten D, Jager A, Sobel RA, Kuchroo VK. 2006a. Myelin oligodendrocyte glycoprotein-specific $\mathrm{T}$ and $\mathrm{B}$ cells cooperate to induce a Devic-like disease in mice. J Clin Invest 116: 2393-2402.

Bettelli E, Carrier Y, Gao W, Korn T, Strom TB, Oukka M, Weiner HL, Kuchroo VK. 2006b. Reciprocal developmental pathways for the generation of pathogenic effector $\mathrm{T}_{\mathrm{H}} 17$ and regulatory T cells. Nature 441: 235-238.

Bhela S, Kempsell C, Manohar M, Dominguez-Villar M, Griffin R, Bhatt P, Kivisakk-Webb P, Fuhlbrigge R, Kupper T, Weiner H, et al. 2015. Nonapoptotic and extracellular activity of granzyme B mediates resistance to regulatory $\mathrm{T}$ cell (Treg) suppression by HLA-DR$\mathrm{CD} 25^{\text {hi }} \mathrm{CD} 127^{\text {lo }}$ Tregs in multiple sclerosis and in response to IL-6. J Immunol 194: 2180-2189.

Boniface K, Blumenschein WM, Brovont-Porth $\mathrm{K}$, McGeachy MJ, Basham B, Desai B, Pierce R, McClanahan TK, Sadekova S, de Waal Malefyt R. 2010. Human Th17 cells comprise heterogeneous subsets including IFN- $\gamma$ producing cells with distinct properties from the Th1 lineage. J Immunol 185: 679-687.

Brennan MS, Matos MF, Li B, Hronowski X, Gao B, Juhasz P, Rhodes KJ, Scannevin RH. 2015. Dimethyl fumarate and monoethyl fumarate exhibit differential effects on KEAP1, NRF2 activation, and glutathione depletion in vitro. PLoS ONE 10: e0120254.

Brinkmann V. 2007. Sphingosine 1-phosphate receptors in health and disease: Mechanistic insights from gene deletion studies and reverse pharmacology. Pharmacol Therapeut 115: 84-105.

Brucklacher-Waldert V, Stuerner K, Kolster M, Wolthausen J, Tolosa E. 2009. Phenotypical and functional characterization of T helper 17 cells in multiple sclerosis. Brain 132: $3329-3341$.
Bushnell SE, Zhao Z, Stebbins CC, Cadavid D, Buko AM, Whalley ET, Davis JA, Versage EM, Richert JR, Axtell RC, et al. 2012. Serum IL-17F does not predict poor response to IM IFN $\beta$-1a in relapsing-remitting MS. Neurology 79: 531-537.

Cerosaletti K, Schneider A, Schwedhelm K, Frank I, Tatum M, Wei S, Whalen E, Greenbaum C, Kita M, Buckner J, et al. 2013. Multiple autoimmune-associated variants confer decreased IL-2R signaling in $\mathrm{CD} 4^{+} \mathrm{CD} 25^{\text {hi }} \mathrm{T}$ cells of type 1 diabetic and multiple sclerosis patients. PLOS ONE 8: e83811.

Chaudhry A, Rudra D, Treuting P, Samstein RM, Liang Y, Kas A, Rudensky AY. 2009. CD4 $4^{+}$regulatory T cells control $\mathrm{T}_{\mathrm{H}} 17$ responses in a Stat3-dependent manner. Science 326: 986-991.

Chen ML, Yan BS, Kozoriz D, Weiner HL. 2009. Novel CD8 ${ }^{+}$ Treg suppress EAE by TGF- $\beta$ - and IFN- $\gamma$-dependent mechanisms. Eur J Immunol 39: 3423-3435.

Chitnis T, Najafian N, Benou C, Salama AD, Grusby MJ, Sayegh MH, Khoury SJ. 2001. Effect of targeted disruption of STAT4 and STAT6 on the induction of experimental autoimmune encephalomyelitis. J Clin Invest 108: 739-747.

Chou YK, Bourdette DN, Offner H, Whitham R, Wang RY, Hashim GA, Vandenbark AA. 1992. Frequency of T cells specific for myelin basic protein and myelin proteolipid protein in blood and cerebrospinal fluid in multiple sclerosis. J Neuroimmunol 38: 105-113.

Codarri L, Gyulveszi G, Tosevski V, Hesske L, Fontana A, Magnenat L, Suter T, Becher B. 2011. ROR $\gamma$ t drives production of the cytokine GM-CSF in helper T cells, which is essential for the effector phase of autoimmune neuroinflammation. Nat Immunol 12: 560-567.

Comabella M, Fernandez-Arquero M, Rio J, Guinea A, Fernandez M, Cenit MC, de la Concha EG, Montalban X 2009a. HLA class I and II alleles and response to treatment with interferon- $\beta$ in relapsing-remitting multiple sclerosis. J Neuroimmunol 210: 116-119.

Comabella M, Lunemann JD, Rio J, Sanchez A, Lopez C, Julia E, Fernandez M, Nonell L, Camina-Tato M, Deisenhammer F, et al. 2009b. A type I interferon signature in monocytes is associated with poor response to interferon$\beta$ in multiple sclerosis. Brain 132: 3353-3365.

Correale J, Villa A. 2008. Isolation and characterization of $\mathrm{CD}^{+}$regulatory $\mathrm{T}$ cells in multiple sclerosis. J Neuroimmunol 195: 121-134.

Crawford MP, Yan SX, Ortega SB, Mehta RS, Hewitt RE, Price DA, Stastny P, Douek DC, Koup RA, Racke MK, et al. 2004. High prevalence of autoreactive, neuroantigen-specific $\mathrm{CD}^{+} \mathrm{T}$ cells in multiple sclerosis revealed by novel flow cytometric assay. Blood 103: 4222-4231.

Cross AH, Trotter JL, Lyons J. 2001. B cells and antibodies in CNS demyelinating disease. J Neuroimmunol 112: 1-14.

Croxford AL, Lanzinger M, Hartmann FJ, Schreiner B, Mair F, Pelczar P, Clausen BE, Jung S, Greter M, Becher B. 2015. The cytokine GM-CSF drives the inflammatory signature of CCR $2^{+}$monocytes and licenses autoimmunity. Immunity 43: 502-514.

Cua DJ, Sherlock J, Chen Y, Murphy CA, Joyce B, Seymour B, Lucian L, To W, Kwan S, Churakova T, et al. 2003 Interleukin-23 rather than interleukin-12 is the critical 
cytokine for autoimmune inflammation of the brain Nature 421: 744-748.

Degenhardt A, Ramagopalan SV, Scalfari A, Ebers GC. 2009. Clinical prognostic factors in multiple sclerosis: A natural history review. Nat Rev Neurol 5: 672-682.

Delarasse C, Daubas P, Mars LT, Vizler C, Litzenburger T, Iglesias A, Bauer J, Della Gaspera B, Schubart A, Decker L, et al. 2003. Myelin/oligodendrocyte glycoproteindeficient (MOG-deficient) mice reveal lack of immune tolerance to MOG in wild-type mice. J Clin Invest 112: 544-553.

Derbinski J, Schulte A, Kyewski B, Klein L. 2001. Promiscuous gene expression in medullary thymic epithelial cells mirrors the peripheral self. Nat Immunol 2: 1032-1039.

Duhen R, Glatigny S, Arbelaez CA, Blair TC, Oukka M, Bettelli E. 2013. Cutting edge: The pathogenicity of IFN- $\gamma$-producing Th17 cells is independent of T-bet. J Immunol 190: 4478-4482.

El-Behi M, Ciric B, Dai H, Yan Y, Cullimore M, Safavi F, Zhang GX, Dittel BN, Rostami A. 2011. The encephalitogenicity of $\mathrm{T}_{\mathrm{H}} 17$ cells is dependent on IL-1- and IL-23induced production of the cytokine GM-CSF. Nat Immunol 12: 568-575.

Ellmerich S, Mycko M, Takacs K, Waldner H, Wahid FN, Boyton RJ, King RH, Smith PA, Amor S, Herlihy AH, et al 2005. High incidence of spontaneous disease in an HLADR15 and TCR transgenic multiple sclerosis model. J Immunol 174: 1938-1946.

Elong Ngono A, Pettre S, Salou M, Bahbouhi B, Soulillou JP, Brouard S, Laplaud DA. 2012. Frequency of circulating autoreactive $\mathrm{T}$ cells committed to myelin determinants in relapsing-remitting multiple sclerosis patients. Clin Immunol 144: 117-126.

Encinas JA, Wicker LS, Peterson LB, Mukasa A, Teuscher C, Sobel R, Weiner HL, Seidman CE, Seidman JG, Kuchroo VK. 1999. QTL influencing autoimmune diabetes and encephalomyelitis map to a $0.15-\mathrm{cM}$ region containing Il2. Nat Genet 21: 158-160.

Feger U, Luther C, Poeschel S, Melms A, Tolosa E, Wiendl H. 2007. Increased frequency of $\mathrm{CD} 4^{+} \mathrm{CD} 25^{+}$regulatory $\mathrm{T}$ cells in the cerebrospinal fluid but not in the blood of multiple sclerosis patients. Clin Exp Immunol 147: 412418.

Fillatreau S, Sweenie CH, McGeachy MJ, Gray D, Anderton SM. 2002. B cells regulate autoimmunity by provision of IL-10. Nat Immunol 3: 944-950.

Foster CA, Howard LM, Schweitzer A, Persohn E, Hiestand PC, Balatoni B, Reuschel R, Beerli C, Schwartz M, Billich A. 2007. Brain penetration of the oral immunomodulatory drug FTY720 and its phosphorylation in the central nervous system during experimental autoimmune encephalomyelitis: Consequences for mode of action in multiple sclerosis. J Pharmacol Exp Ther 323: 469-475.

Foster CA, Mechtcheriakova D, Storch MK, Balatoni B, Howard LM, Bornancin F, Wlachos A, Sobanov J, Kinnunen A, Baumruker T. 2009. FTY720 rescue therapy in the dark agouti rat model of experimental autoimmune encephalomyelitis: Expression of central nervous system genes and reversal of blood-brain-barrier damage. Brain Pathol 19: 254-266.

Friese MA, Jakobsen KB, Friis L, Etzensperger R, Craner MJ, McMahon RM, Jensen LT, Huygelen V, Jones EY, Bell JI, et al. 2008. Opposing effects of HLA class I molecules in tuning autoreactive $\mathrm{CD} 8^{+} \mathrm{T}$ cells in multiple sclerosis. Nat Med 14: 1227-1235.

Frischer JM, Bramow S, Dal-Bianco A, Lucchinetti CF, Rauschka H, Schmidbauer M, Laursen H, Sorensen PS, Lassmann H. 2009. The relation between inflammation and neurodegeneration in multiple sclerosis brains. Brain 132: 1175-1189.

Fritz RB, Chou CH, McFarlin DE. 1983. Induction of experimental allergic encephalomyelitis in PL/J and (SJL/JxPL/ J) F1 mice by myelin basic protein and its peptides: Localization of a second encephalitogenic determinant. J Immunol 130: 191-194.

Gartner D, Hoff H, Gimsa U, Burmester GR, BrunnerWeinzierl MC. 2006. CD25 regulatory T cells determine secondary but not primary remission in EAE: Impact on long-term disease progression. J Neuroimmunol 172: 7384 .

Ghezzi A, Martinelli V, Torri V, Zaffaroni M, Rodegher M, Comi G, Zibetti A, Canal N. 1999. Long-term follow-up of isolated optic neuritis: The risk of developing multiple sclerosis, its outcome, and the prognostic role of paraclinical tests. J Neurol 246: 770-775.

Ghoreschi K, Laurence A, Yang XP, Tato CM, McGeachy MJ, Konkel JE, Ramos HL, Wei L, Davidson TS, Bouladoux N, et al. 2010. Generation of pathogenic $\mathrm{T}_{\mathrm{H}} 17$ cells in the absence of TGF- $\beta$ signalling. Nature 467: 967-971.

Givogri MI, Bongarzone ER, Campagnoni AT. 2000. New insights on the biology of myelin basic protein gene: The neural-immune connection. J Neurosci Res 59: 153-159.

Glatigny S, Duhen R, Oukka M, Bettelli E. 2011. Cutting edge: Loss of $\alpha 4$ integrin expression differentially affects the homing of Th1 and Th17 cells. J Immunol 187: 61766179.

Glatigny S, Duhen R, Arbelaez C, Kumari S, Bettelli E. 2015. Integrin $\alpha \mathrm{L}$ controls the homing of regulatory $\mathrm{T}$ cells during CNS autoimmunity in the absence of integrin $\alpha 4$. Sci Rep 5: 7834.

Glatigny S, Wagner CA, Bettelli E. 2016. Cutting edge: Integrin $\alpha 4$ is required for regulatory B cell control of experimental autoimmune encephalomyelitis. JImmunol 196: $3542-3546$

Glimcher LH, Murphy KM. 2000. Lineage commitment in the immune system: The T helper lymphocyte grows up. Genes Dev 14: 1693-1711.

Gocke AR, Cravens PD, Ben LH, Hussain RZ, Northrop SC, Racke MK, Lovett-Racke AE. 2007. T-bet regulates the fate of Th1 and Th17 lymphocytes in autoimmunity. J Immunol 178: 1341-1348.

Goverman JM. 2011. Immune tolerance in multiple sclerosis. Immunol Rev 241: 228-240.

Goverman J, Woods A, Larson L, Weiner LP, Hood L, Zaller DM. 1993. Transgenic mice that express a myelin basic protein-specific $\mathrm{T}$ cell receptor develop spontaneous autoimmunity. Cell 72: 551-560.

Gregersen JW, Kranc KR, Ke X, Svendsen P, Madsen LS, Thomsen AR, Cardon LR, Bell JI, Fugger L. 2006. Functional epistasis on a common MHC haplotype associated with multiple sclerosis. Nature 443: 574-577. 
Grifka-Walk HM, Lalor SJ, Segal BM. 2013. Highly polarized Th17 cells induce EAE via a T-bet independent mechanism. Eur J Immunol 43: 2824-2831.

Gutcher I, Becher B. 2007. APC-derived cytokines and T cell polarization in autoimmune inflammation. J Clin Invest 117: 1119-1127.

Haak S, Croxford AL, Kreymborg K, Heppner FL, Pouly S, Becher B, Waisman A. 2009. IL-17A and IL-17F do not contribute vitally to autoimmune neuro-inflammation in mice. J Clin Invest 119: 61-69.

Haas J, Hug A, Viehover A, Fritzsching B, Falk CS, Filser A, Vetter T, Milkova L, Korporal M, Fritz B, et al. 2005. Reduced suppressive effect of $\mathrm{CD} 4^{+} \mathrm{CD} 25^{\text {high }}$ regulatory $\mathrm{T}$ cells on the $\mathrm{T}$ cell immune response against myelin oligodendrocyte glycoprotein in patients with multiple sclerosis. Eur J Immunol 35: 3343-3352.

Harrington LE, Hatton RD, Mangan PR, Turner H, Murphy TL, Murphy KM, Weaver CT. 2005. Interleukin 17-producing $\mathrm{CD}^{+}$effector $\mathrm{T}$ cells develop via a lineage distinct from the T helper type 1 and 2 lineages. Nat Immunol 6: 1123-1132.

Harris TJ, Grosso JF, Yen HR, Xin H, Kortylewski M, Albesiano E, Hipkiss EL, Getnet D, Goldberg MV, Maris CH, et al. 2007. Cutting edge: An in vivo requirement for STAT3 signaling in $\mathrm{T}_{\mathrm{H}} 17$ development and $\mathrm{T}_{\mathrm{H}} 17$-dependent autoimmunity. J Immunol 179: 4313-4317.

Hartmann FJ, Khademi M, Aram J, Ammann S, Kockum I, Constantinescu C, Gran B, Piehl F, Olsson T, Codarri L, et al. 2014. Multiple sclerosis-associated IL2RA polymorphism controls GM-CSF production in human $\mathrm{T}_{\mathrm{H}}$ cells. Nat Commun 5: 5056.

Hauser SL, Waubant E, Arnold DL, Vollmer T, Antel J, Fox RJ, Bar-Or A, Panzara M, Sarkar N, Agarwal S, et al. 2008. $\mathrm{B}$-cell depletion with rituximab in relapsing-remitting multiple sclerosis. N Engl J Med 358: 676-688.

Hirota K, Duarte JH, Veldhoen M, Hornsby E, Li Y, Cua DJ, Ahlfors H, Wilhelm C, Tolaini M, Menzel U, et al. 2011. Fate mapping of IL-17-producing T cells in inflammatory responses. Nat Immunol 12: 255-263.

Hofstetter HH, Ibrahim SM, Koczan D, Kruse N, Weishaupt A, Toyka KV, Gold R. 2005. Therapeutic efficacy of IL-17 neutralization in murine experimental autoimmune encephalomyelitis. Cell Immunol 237: 123-130.

Hori S, Haury M, Coutinho A, Demengeot J. 2002. Specificity requirements for selection and effector functions of $\mathrm{CD} 25^{+} 4^{+}$regulatory $\mathrm{T}$ cells in anti-myelin basic protein $\mathrm{T}$ cell receptor transgenic mice. Proc Natl Acad Sci 99: 8213-8218.

Huizinga R, Hintzen RQ, Assink K, van Meurs M, Amor S. 2009. T-cell responses to neurofilament light protein are part of the normal immune repertoire. Int Immunol 21: 433-441.

Huseby ES, Liggitt D, Brabb T, Schnabel B, Ohlen C, Goverman J. 2001a. A pathogenic role for myelin-specific $\mathrm{CD}^{+}$ T cells in a model for multiple sclerosis. J Exp Med 194: 669-676.

Huseby ES, Sather B, Huseby PG, Goverman J. 2001b. Agedependent $\mathrm{T}$ cell tolerance and autoimmunity to myelin basic protein. Immunity 14: 471-481.

Iglesias A, Bauer J, Litzenburger T, Schubart A, Linington C. 2001. T- and B-cell responses to myelin oligodendrocyte glycoprotein in experimental autoimmune encephalomyelitis and multiple sclerosis. Glia 36: 220-234.

Ivanov II, McKenzie BS, Zhou L, Tadokoro CE, Lepelley A, Lafaille JJ, Cua DJ, Littman DR. 2006. The orphan nuclear receptor ROR $\gamma \mathrm{t}$ directs the differentiation program of proinflammatory IL- $17^{+} \mathrm{T}$ helper cells. Cell 126: $1121-$ 1133.

Jager A, Dardalhon V, Sobel RA, Bettelli E, Kuchroo VK. 2009. Th1, Th17, and Th9 effector cells induce experimental autoimmune encephalomyelitis with different pathological phenotypes. J Immunol 183: 7169-7177.

Ji Q, Perchellet A, Goverman JM. 2010. Viral infection triggers central nervous system autoimmunity via activation of $\mathrm{CD}^{+} \mathrm{T}$ cells expressing dual TCRs. Nat Immunol 11: 628-634.

Jiang H, Braunstein NS, Yu B, Winchester R, Chess L. 2001. $\mathrm{CD}^{+} \mathrm{T}$ cells control the $\mathrm{T}_{\mathrm{H}}$ phenotype of MBP-reactive $\mathrm{CD}^{+}{ }^{+} \mathrm{T}$ cells in EAE mice. Proc Natl Acad Sci 98: 63016306.

Johnson KP, Brooks BR, Cohen JA, Ford CC, Goldstein J, Lisak RP, Myers LW, Panitch HS, Rose JW, Schiffer RB. 1995. Copolymer 1 reduces relapse rate and improves disability in relapsing-remitting multiple sclerosis: Results of a phase III multicenter, double-blind placebocontrolled trial. The Copolymer 1 Multiple Sclerosis Study Group. Neurology 45: 1268-1276.

Josefowicz SZ, Lu LF, Rudensky AY. 2012. Regulatory T cells: Mechanisms of differentiation and function. Annu Rev Immunol 30: 531-564.

Jurewicz A, Biddison WE, Antel JP. 1998. MHC class I-restricted lysis of human oligodendrocytes by myelin basic protein peptide-specific CD8 T lymphocytes. J Immunol 160: 3056-3059.

Kabat EA, Moore DH, Landow H. 1942. An electrophoretic study of the protein components in cerebrospinal fluid and their relationship to the serum proteins. J Clin Invest 21: 571-577.

Kappos L, Li D, Calabresi PA, O'Connor P, Bar-Or A, Barkhof F, Yin M, Leppert D, Glanzman R, Tinbergen J, et al. 2011. Ocrelizumab in relapsing-remitting multiple sclerosis: A phase 2, randomised, placebo-controlled, multicentre trial. Lancet 378: 1779-1787.

Karandikar NJ, Crawford MP, Yan X, Ratts RB, Brenchley JM, Ambrozak DR, Lovett-Racke AE, Frohman EM, Stastny P, Douek DC, et al. 2002. Glatiramer acetate (Copaxone) therapy induces $\mathrm{CD}^{+} \mathrm{T}$ cell responses in patients with multiple sclerosis. J Clin Invest 109: 641-649.

Karcher D, Van Sande M, Lowenthal A. 1959. Micro-electrophoresis in agar gel of proteins of the cerebrospinal fluid and central nervous system. J Neurochem 4: 135140.

Kataoka H, Sugahara K, Shimano K, Teshima K, Koyama M, Fukunari A, Chiba K. 2005. FTY720, sphingosine 1-phosphate receptor modulator, ameliorates experimental autoimmune encephalomyelitis by inhibition of $\mathrm{T}$ cell infiltration. Cell Mol Immunol 2: 439-448.

Kebir H, Ifergan I, Alvarez JI, Bernard M, Poirier J, Arbour N, Duquette P, Prat A. 2009. Preferential recruitment of interferon- $\gamma$-expressing $\mathrm{T}_{\mathrm{H}} 17$ cells in multiple sclerosis. Ann Neurol 66: 390-402.

Kerlero de Rosbo N, Milo R, Lees MB, Burger D, Bernard CC, Ben-Nun A. 1993. Reactivity to myelin antigens in 
multiple sclerosis. Peripheral blood lymphocytes respond predominantly to myelin oligodendrocyte glycoprotein. J Clin Invest 92: 2602-2608.

Kerlero de Rosbo N, Mendel I, Ben-Nun A. 1995. Chronic relapsing experimental autoimmune encephalomyelitis with a delayed onset and an atypical clinical course, induced in PL/J mice by myelin oligodendrocyte glycoprotein (MOG)-derived peptide: Preliminary analysis of MOG T cell epitopes. Eur J Immunol 25: 985-993.

Kerlero de Rosbo N, Hoffman M, Mendel I, Yust I, Kaye J, Bakimer R, Flechter S, Abramsky O, Milo R, Karni A, et al. 1997. Predominance of the autoimmune response to myelin oligodendrocyte glycoprotein (MOG) in multiple sclerosis: Reactivity to the extracellular domain of MOG is directed against three main regions. Eur J Immunol 27: 3059-3069.

Khan AR, Hams E, Floudas A, Sparwasser T, Weaver CT, Fallon PG. 2015. PD-L1 ${ }^{\text {hi }}$ B cells are critical regulators of humoral immunity. Nat Commun 6: 5997.

Kihara Y, Groves A, Rivera RR, Chun J. 2015. Dimethyl fumarate inhibits integrin $\alpha 4$ expression in multiple sclerosis models. Ann Clin Transl Neurol 2: 978-983.

Ko HJ, Brady JL, Ryg-Cornejo V, Hansen DS, Vremec D, Shortman K, Zhan Y, Lew AM. 2014. GM-CSF-responsive monocyte-derived dendritic cells are pivotal in Th17 pathogenesis. J Immunol 192: 2202-2209.

Koch MA, Tucker-Heard G, Perdue NR, Killebrew JR, Urdahl KB, Campbell DJ. 2009. The transcription factor Tbet controls regulatory $\mathrm{T}$ cell homeostasis and function during type 1 inflammation. Nat Immunol 10: 595-602.

Koh DR, Fung-Leung WP, Ho A, Gray D, Acha-Orbea H, Mak TW. 1992. Less mortality but more relapses in experimental allergic encephalomyelitis in $\mathrm{CD}^{--}$mice. Science 256: 1210-1213.

Kohm AP, Carpentier PA, Anger HA, Miller SD. 2002. Cutting edge: $\mathrm{CD} 4^{+} \mathrm{CD} 25^{+}$regulatory $\mathrm{T}$ cells suppress antigen-specific autoreactive immune responses and central nervous system inflammation during active experimental autoimmune encephalomyelitis. J Immunol 169: 47124716.

Komiyama Y, Nakae S, Matsuki T, Nambu A, Ishigame H, Kakuta S, Sudo K, Iwakura Y. 2006. IL-17 plays an important role in the development of experimental autoimmune encephalomyelitis. J Immunol 177: 566-573.

Korn T, Reddy J, Gao W, Bettelli E, Awasthi A, Petersen TR, Backstrom BT, Sobel RA, Wucherpfennig KW, Strom TB, et al. 2007. Myelin-specific regulatory T cells accumulate in the CNS but fail to control autoimmune inflammation. Nat Med 13: 423-431.

Korn T, Bettelli E, Oukka M, Kuchroo VK. 2009. IL-17 and Th17 cells. Annu Rev Immunol 27: 485-517.

Koutrolos M, Berer K, Kawakami N, Wekerle H, Krishnamoorthy G. 2014. Treg cells mediate recovery from EAE by controlling effector $\mathrm{T}$ cell proliferation and motility in the CNS. Acta Neuropathol Commun 2: 163.

Krishnamoorthy G, Lassmann H, Wekerle H, Holz A. 2006. Spontaneous opticospinal encephalomyelitis in a doubletransgenic mouse model of autoimmune $\mathrm{T}$ cell/B cell cooperation. J Clin Invest 116: 2385-2392.

Kroenke MA, Carlson TJ, Andjelkovic AV, Segal BM. 2008. IL-12- and IL-23-modulated T cells induce distinct types of EAE based on histology, CNS chemokine profile, and response to cytokine inhibition. J Exp Med 205: 15351541.

Lafaille JJ, Nagashima K, Katsuki M, Tonegawa S. 1994. High incidence of spontaneous autoimmune encephalomyelitis in immunodeficient anti-myelin basic protein $\mathrm{T}$ cell receptor transgenic mice. Cell 78: 399-408.

Langrish CL, Chen Y, Blumenschein WM, Mattson J, Basham B, Sedgwick JD, McClanahan T, Kastelein RA, Cua DJ. 2005. IL-23 drives a pathogenic $T$ cell population that induces autoimmune inflammation. J Exp Med 201: 233240.

Lassmann H, Bruck W, Lucchinetti CF. 2007. The immunopathology of multiple sclerosis: An overview. Brain Pathol 17: 210-218.

Laurence A, Tato CM, Davidson TS, Kanno Y, Chen Z, Yao Z, Blank RB, Meylan F, Siegel R, Hennighausen L, et al. 2007. Interleukin-2 signaling via STAT5 constrains $T$ helper 17 cell generation. Immunity 26: 371-381.

Lee YH, Ishida Y, Rifa'i M, Shi Z, Isobe K, Suzuki H. 2008. Essential role of $\mathrm{CD} 8^{+} \mathrm{CD} 122^{+}$regulatory $\mathrm{T}$ cells in the recovery from experimental autoimmune encephalomyelitis. J Immunol 180: 825-832.

Lee Y, Awasthi A, Yosef N, Quintana FJ, Xiao S, Peters A, Wu C, Kleinewietfeld M, Kunder S, Hafler DA, et al. 2012. Induction and molecular signature of pathogenic $\mathrm{T}_{\mathrm{H}} 17$ cells. Nat Immunol 13: 991-999.

Lemke G. 1988. Unwrapping the genes of myelin. Neuron 1: 535-543.

Leuenberger T, Paterka M, Reuter E, Herz J, Niesner RA, Radbruch H, Bopp T, Zipp F, Siffrin V. 2013. The role of $\mathrm{CD}^{+} \mathrm{T}$ cells and their local interaction with $\mathrm{CD}^{+} \mathrm{T}$ cells in myelin oligodendrocyte glycoprotein $35-$ 55-induced experimental autoimmune encephalomyelitis. J Immunol 191: 4960-4968.

Liblau R, Tournier-Lasserve E, Maciazek J, Dumas G, Siffert O, Hashim G, Bach MA. 1991. T cell response to myelin basic protein epitopes in multiple sclerosis patients and healthy subjects. Eur J Immunol 21: 1391-1395.

Lin CC, Bradstreet TR, Schwarzkopf EA, Sim J, Carrero JA, Chou C, Cook LE, Egawa T, Taneja R, Murphy TL, et al. 2014. Bhlhe40 controls cytokine production by T cells and is essential for pathogenicity in autoimmune neuroinflammation. Nat Commun 5: 3551.

Linington C, Bradl M, Lassmann H, Brunner C, Vass K. 1988. Augmentation of demyelination in rat acute allergic encephalomyelitis by circulating mouse monoclonal antibodies directed against a myelin/oligodendrocyte glycoprotein. Am J Pathol 130: 443-454.

Link J, Soderstrom M, Olsson T, Hojeberg B, Ljungdahl A, Link H. 1994. Increased transforming growth factor- $\beta$, interleukin- 4 , and interferon- $\gamma$ in multiple sclerosis. Ann Neurol 36: 379-386.

Linker RA, Lee DH, Ryan S, van Dam AM, Conrad R, Bista P, Zeng W, Hronowsky X, Buko A, Chollate S, et al. 2011. Fumaric acid esters exert neuroprotective effects in neuroinflammation via activation of the Nrf2 antioxidant pathway. Brain 134: 678-692.

Litzenburger T, Fassler R, Bauer J, Lassmann H, Linington C, Wekerle H, Iglesias A. 1998. B lymphocytes producing demyelinating autoantibodies: Development and function in gene-targeted transgenic mice. J Exp Med 188: $169-180$. 
Lock C, Hermans G, Pedotti R, Brendolan A, Schadt E Garren H, Langer-Gould A, Strober S, Cannella B, Allard J, et al. 2002. Gene-microarray analysis of multiple sclerosis lesions yields new targets validated in autoimmune encephalomyelitis. Nat Med 8: 500-508.

Lowenthal A, Vansande M, Karcher D. 1960. The differential diagnosis of neurological diseases by fractionating electrophoretically the CSF $\gamma$-globulins. J Neurochem 6: 51-56.

Lyons JA, San M, Happ MP, Cross AH. 1999. B cells are critical to induction of experimental allergic encephalomyelitis by protein but not by a short encephalitogenic peptide. Eur J Immunol 29: 3432-3439.

Madsen LS, Andersson EC, Jansson L, Krogsgaard M, Andersen CB, Engberg J, Strominger JL, Svejgaard A, Hjorth JP, Holmdahl R, et al. 1999. A humanized model for multiple sclerosis using HLA-DR2 and a human T-cell receptor. Nat Genet 23: 343-347.

Magliozzi R, Howell O, Vora A, Serafini B, Nicholas R, Puopolo M, Reynolds R, Aloisi F. 2007. Meningeal B-cell follicles in secondary progressive multiple sclerosis associate with early onset of disease and severe cortical pathology. Brain 130: 1089-1104.

Martinez-Llordella M, Esensten JH, Bailey-Bucktrout SL, Lipsky RH, Marini A, Chen J, Mughal M, Mattson MP, Taub DD, Bluestone JA. 2013. CD28-inducible transcription factor DEC1 is required for efficient autoreactive $\mathrm{CD}^{+} \mathrm{T}$ cell response. J Exp Med 210: 1603-1619.

Mathur AN, Chang HC, Zisoulis DG, Stritesky GL, Yu Q, O’Malley JT, Kapur R, Levy DE, Kansas GS, Kaplan MH. 2007. Stat 3 and Stat 4 direct development of IL-17-secreting Th cells. J Immunol 178: 4901-4907.

Matloubian M, Lo CG, Cinamon G, Lesneski MJ, Xu Y, Brinkmann V, Allende ML, Proia RL, Cyster JG. 2004. Lymphocyte egress from thymus and peripheral lymphoid organs is dependent on S1P receptor 1. Nature 427: 355-360.

Matsumoto M, Baba A, Yokota T, Nishikawa H, Ohkawa Y, Kayama H, Kallies A, Nutt SL, Sakaguchi S, Takeda K, et al. 2014. Interleukin-10-producing plasmablasts exert regulatory function in autoimmune inflammation. Immunity 41 1040-1051.

McGeachy MJ, Stephens LA, Anderton SM. 2005. Natural recovery and protection from autoimmune encephalomyelitis: Contribution of $\mathrm{CD} 4^{+} \mathrm{CD} 25^{+}$regulatory cells within the central nervous system. J Immunol 175: 3025-3032.

McQualter JL, Darwiche R, Ewing C, Onuki M, Kay TW, Hamilton JA, Reid HH, Bernard CC. 2001. Granulocyte macrophage colony-stimulating factor: A new putative therapeutic target in multiple sclerosis. J Exp Med 194: 873-882

McRae BL, Kennedy MK, Tan LJ, Dal Canto MC, Picha KS, Miller SD. 1992. Induction of active and adoptive relapsing experimental autoimmune encephalomyelitis (EAE) using an encephalitogenic epitope of proteolipid protein. J Neuroimmunol 38: 229-240.

McRae BL, Vanderlugt CL, Dal Canto MC, Miller SD. 1995 Functional evidence for epitope spreading in the relapsing pathology of experimental autoimmune encephalomyelitis. J Exp Med 182: 75-85.

Mendel I, Kerlero de Rosbo N, Ben-Nun A. 1995. A myelin oligodendrocyte glycoprotein peptide induces typical chronic experimental autoimmune encephalomyelitis in $\mathrm{H}-2^{\mathrm{b}}$ mice: Fine specificity and $\mathrm{T}$ cell receptor $\mathrm{V} \beta$ expression of encephalitogenic T cells. Eur J Immunol 25: 19511959.

Mendel I, Kerlero de Rosbo N, Ben-Nun A. 1996. Delineation of the minimal encephalitogenic epitope within the immunodominant region of myelin oligodendrocyte glycoprotein: Diverse V $\beta$ gene usage by T cells recognizing the core epitope encephalitogenic for $\mathrm{T}$ cell receptor $\mathrm{V} \beta^{\mathrm{b}}$ and $\mathrm{T}$ cell receptor $\mathrm{V} \beta^{\mathrm{a}} \mathrm{H}-2^{\mathrm{b}}$ mice. Eur J Immunol 26: 2470-2479.

Merrill JE, Hanak S, Pu SF, Liang J, Dang C, Iglesias-Bregna D, Harvey B, Zhu B, McMonagle-Strucko K. 2009. Teriflunomide reduces behavioral, electrophysiological, and histopathological deficits in the Dark Agouti rat model of experimental autoimmune encephalomyelitis. J Neurol 256: 89-103.

Michel L, Berthelot L, Pettre S, Wiertlewski S, Lefrere F, Braudeau C, Brouard S, Soulillou JP, Laplaud DA. 2008. Patients with relapsing-remitting multiple sclerosis have normal Treg function when cells expressing IL-7 receptor $\alpha$-chain are excluded from the analysis. J Clin Invest 118 : 3411-3419.

Mildner A, Mack M, Schmidt H, Bruck W, Djukic M, Zabel MD, Hille A, Priller J, Prinz M. 2009. CCR $2^{+} L y-6 C^{\text {hi }}$ monocytes are crucial for the effector phase of autoimmunity in the central nervous system. Brain 132: 24872500.

Miller DH, Khan OA, Sheremata WA, Blumhardt LD, Rice GP, Libonati MA, Willmer-Hulme AJ, Dalton CM, Miszkiel KA, O'Connor PW, et al. 2003. A controlled trial of natalizumab for relapsing multiple sclerosis. $N$ Engl $J$ Med 348: 15-23.

Molnarfi N, Schulze-Topphoff U, Weber MS, Patarroyo JC, Prod'homme T, Varrin-Doyer M, Shetty A, Linington C, Slavin AJ, Hidalgo J, et al. 2013. MHC class II-dependent $\mathrm{B}$ cell APC function is required for induction of CNS autoimmunity independent of myelin-specific antibodies. J Exp Med 210: 2921-2937.

Montero E, Nussbaum G, Kaye JF, Perez R, Lage A, Ben-Nun A, Cohen IR. 2004. Regulation of experimental autoimmune encephalomyelitis by $\mathrm{CD} 4^{+}, \mathrm{CD} 25^{+}$and $\mathrm{CD}^{+} \mathrm{T}$ cells: Analysis using depleting antibodies. J Autoimmun 23: 1-7.

Montes M, Zhang X, Berthelot L, Laplaud DA, Brouard S, Jin J, Rogan S, Armao D, Jewells V, Soulillou JP, et al. 2009. Oligoclonal myelin-reactive $\mathrm{T}$-cell infiltrates derived from multiple sclerosis lesions are enriched in Th17 cells. Clin Immunol 130: 133-144.

Mosmann TR, Coffman RL. 1989. $\mathrm{T}_{\mathrm{H}} 1$ and $\mathrm{T}_{\mathrm{H}} 2$ cells: Different patterns of lymphokine secretion lead to different functional properties. Annu Rev Immunol 7: 145-173.

Munder M, Bettelli E, Monney L, Slavik JM, Nicholson LB, Kuchroo VK. 2002. Reduced self-reactivity of an autoreactive $T$ cell after activation with cross-reactive nonself-ligand. J Exp Med 196: 1151-1162.

Najafian N, Chitnis T, Salama AD, Zhu B, Benou C, Yuan X, Clarkson MR, Sayegh MH, Khoury SJ. 2003. Regulatory functions of $\mathrm{CD}^{+} \mathrm{CD} 28^{-} \mathrm{T}$ cells in an autoimmune disease model. J Clin Invest 112: 1037-1048.

Noster R, Riedel R, Mashreghi MF, Radbruch H, Harms L, Haftmann C, Chang HD, Radbruch A, Zielinski CE. 2014 
IL-17 and GM-CSF expression are antagonistically regulated by human T helper cells. Sci Transl Med 6: $241 \mathrm{ra} 280$.

O'Connor RA, Malpass KH, Anderton SM. 2007. The inflamed central nervous system drives the activation and rapid proliferation of Foxp $3^{+}$regulatory T cells. J Immunol 179: 958-966.

O'Connor RA, Cambrook H, Huettner K, Anderton SM. 2013. T-bet is essential for Th1-mediated, but not Th17-mediated, CNS autoimmune disease. Eur J Immunol 43: 2818-2823.

Oh J, O'Connor PW. 2014. Teriflunomide in the treatment of multiple sclerosis: Current evidence and future prospects. Ther Adv Neurol Disord 7: 239-252.

Olivares-Villagomez D, Wang Y, Lafaille JJ. 1998. Regulatory $\mathrm{CD}^{+} \mathrm{T}$ cells expressing endogenous $\mathrm{T}$ cell receptor chains protect myelin basic protein-specific transgenic mice from spontaneous autoimmune encephalomyelitis. J Exp Med 188: 1883-1894.

Ota K, Matsui M, Milford EL, Mackin GA, Weiner HL, Hafler DA. 1990. T-cell recognition of an immunodominant myelin basic protein epitope in multiple sclerosis. Nature 346: 183-187.

Panitch HS, Hirsch RL, Haley AS, Johnson KP. 1987. Exacerbations of multiple sclerosis in patients treated with $\gamma$ interferon. Lancet 1: 893-895.

Park H, Li Z, Yang XO, Chang SH, Nurieva R, Wang YH, Wang Y, Hood L, Zhu Z, Tian Q, et al. 2005. A distinct lineage of $\mathrm{CD} 4 \mathrm{~T}$ cells regulates tissue inflammation by producing interleukin 17. Nat Immunol 6: 1133-1141.

Pender MP, Tabi Z, Nguyen KB, McCombe PA. 1995. The proximal peripheral nervous system is a major site of demyelination in experimental autoimmune encephalomyelitis induced in the Lewis rat by a myelin basic protein-specific T cell clone. Acta Neuropathol 89: 527-531.

Perchellet A, Stromnes I, Pang JM, Goverman J. 2004. CD8 ${ }^{+}$ $\mathrm{T}$ cells maintain tolerance to myelin basic protein by "epitope theft." Nat Immunol 5: 606-614.

Perdigoto AL, Chatenoud L, Bluestone JA, Herold KC. 2015. Inducing and administering tregs to treat human disease. Front Immunol 6: 654.

Peters A, Pitcher LA, Sullivan JM, Mitsdoerffer M, Acton SE, Franz B, Wucherpfennig K, Turley S, Carroll MC, Sobel RA, et al. 2011. Th17 cells induce ectopic lymphoid follicles in central nervous system tissue inflammation. Immunity 35: 986-996.

Pettinelli CB, Fritz RB, Chou CH, McFarlin DE. 1982. Encephalitogenic activity of guinea pig myelin basic protein in the SJL mouse. J Immunol 129: 1209-1211.

Pollinger B, Krishnamoorthy G, Berer K, Lassmann H, Bosl MR, Dunn R, Domingues HS, Holz A, Kurschus FC, Wekerle H. 2009. Spontaneous relapsing-remitting EAE in the SJL/J mouse: MOG-reactive transgenic T cells recruit endogenous MOG-specific B cells. J Exp Med 206: 1303-1316.

Putheti P, Pettersson A, Soderstrom M, Link H, Huang YM. 2004. Circulating $\mathrm{CD} 4^{+} \mathrm{CD} 25^{+} \mathrm{T}$ regulatory cells are not altered in multiple sclerosis and unaffected by diseasemodulating drugs. J Clin Immunol 24: 155-161.

Quandt JA, Huh J, Baig M, Yao K, Ito N, Bryant M, Kawamura K, Pinilla C, McFarland HF, Martin R, et al. 2012 Myelin basic protein-specific TCR/HLA-DRB5*01:01 transgenic mice support the etiologic role of DRB5*01:01 in multiple sclerosis. J Immunol 189: 2897-2908.

Raddassi K, Kent SC, Yang J, Bourcier K, Bradshaw EM, Seyfert-Margolis V, Nepom GT, Kwok WW, Hafler DA. 2011. Increased frequencies of myelin oligodendrocyte glycoprotein/MHC class II-binding CD4 cells in patients with multiple sclerosis. J Immunol 187: 1039-1046.

Ray A, Basu S, Williams CB, Salzman NH, Dittel BN. 2012. A novel IL-10-independent regulatory role for B cells in suppressing autoimmunity by maintenance of regulatory T cells via GITR ligand. J Immunol 188: 3188-3198.

Reddy J, Illes Z, Zhang X, Encinas J, Pyrdol J, Nicholson L, Sobel RA, Wucherpfennig KW, Kuchroo VK. 2004. Myelin proteolipid protein-specific $\mathrm{CD} 4{ }^{+} \mathrm{CD} 25^{+}$regulatory cells mediate genetic resistance to experimental autoimmune encephalomyelitis. Proc Natl Acad Sci 101: 15434-15439.

Reddy J, Waldner H, Zhang X, Illes Z, Wucherpfennig KW, Sobel RA, Kuchroo VK. 2005. Cutting edge: $\mathrm{CD} 4^{+} \mathrm{CD} 25^{+}$ regulatory $\mathrm{T}$ cells contribute to gender differences in susceptibility to experimental autoimmune encephalomyelitis. J Immunol 175: 5591-5595.

Ringheim GE, Lee L, Laws-Ricker L, Delohery T, Liu L, Zhang D, Colletti N, Soos TJ, Schroeder K, Fanelli B, et al. 2013. Teriflunomide attenuates immunopathological changes in the dark agouti rat model of experimental autoimmune encephalomyelitis. Front Neurol 4: 169.

Rivers TM, Sprunt DH, Berry GP. 1933. Observations on attempts to produce acute disseminated encephalomyelitis in monkeys. J Exp Med 58: 39-53.

Rohn TA, Jennings GT, Hernandez M, Grest P, Beck M, Zou Y, Kopf M, Bachmann MF. 2006. Vaccination against IL17 suppresses autoimmune arthritis and encephalomyelitis. Eur J Immunol 36: 2857-2867.

Ronchi F, Basso C, Preite S, Reboldi A, Baumjohann D, Perlini L, Lanzavecchia A, Sallusto F. 2016. Experimental priming of encephalitogenic Th1/Th17 cells requires pertussis toxin-driven IL-1 $\beta$ production by myeloid cells. Nat Commun 7: 11541.

Rothhammer V, Heink S, Petermann F, Srivastava R, Claussen MC, Hemmer B, Korn T. 2011. Th17 lymphocytes traffic to the central nervous system independently of $\alpha 4$ integrin expression during EAE. J Exp Med 208: 24652476.

Rubtsov YP, Rasmussen JP, Chi EY, Fontenot J, Castelli L, Ye X, Treuting P, Siewe L, Roers A, Henderson WR Jr, et al. 2008. Regulatory T cell-derived interleukin-10 limits inflammation at environmental interfaces. Immunity 28: 546-558.

Sakaguchi S. 2005. Naturally arising Foxp3-expressing $\mathrm{CD} 25^{+} \mathrm{CD} 4^{+}$regulatory $\mathrm{T}$ cells in immunological tolerance to self and non-self. Nat Immunol 6: 345-352.

Sakaguchi S, Sakaguchi N. 2005. Regulatory T cells in immunologic self-tolerance and autoimmune disease. Int Rev Immunol 24: 211-226.

Sakai K, Zamvil SS, Mitchell DJ, Lim M, Rothbard JB, Steinman L. 1988. Characterization of a major encephalitogenic T cell epitope in SJL/J mice with synthetic oligopeptides of myelin basic protein. J Neuroimmunol 19: 21-32.

Sasaki K, Bean A, Shah S, Schutten E, Huseby PG, Peters B, Shen ZT, Vanguri V, Liggitt D, Huseby ES. 2014. Relapsing-remitting central nervous system autoimmunity me- 
diated by GFAP-specific CD8 T cells. J Immunol 192: 3029-3042.

Schneider A, Rieck M, Sanda S, Pihoker C, Greenbaum C, Buckner JH. 2008. The effector T cells of diabetic subjects are resistant to regulation via $\mathrm{CD} 4{ }^{+} \mathrm{FOXP}^{+}$regulatory $\mathrm{T}$ cells. J Immunol 181: 7350-7355.

Schulze-Topphoff U, Varrin-Doyer M, Pekarek K, Spencer CM, Shetty A, Sagan SA, Cree BA, Sobel RA, Wipke BT, Steinman L, et al. 2016. Dimethyl fumarate treatment induces adaptive and innate immune modulation independent of Nrf2. Proc Natl Acad Sci 113: 4777-4782.

Schwab N, Schneider-Hohendorf T, Pignolet B, Breuer J, Gross CC, Gobel K, Brassat D, Wiendl H. 2016. Therapy with natalizumab is associated with high JCV seroconversion and rising JCV index values. Neurol Neuroimmunol Neuroinflamm 3: e195.

Segal BM, Shevach EM. 1996. IL-12 unmasks latent autoimmune disease in resistant mice. J Exp Med 184: 771-775.

Serafini B, Rosicarelli B, Magliozzi R, Stigliano E, Aloisi F 2004. Detection of ectopic B-cell follicles with germinal centers in the meninges of patients with secondary progressive multiple sclerosis. Brain Pathol 14: 164-174.

Shen P, Roch T, Lampropoulou V, O'Connor RA, Stervbo U, Hilgenberg E, Ries S, Dang VD, Jaimes Y, Daridon C, et al. 2014. IL-35-producing B cells are critical regulators of immunity during autoimmune and infectious diseases. Nature 507: 366-370.

Sheng W, Yang F, Zhou Y, Yang H, Low PY, Kemeny DM, Tan P, Moh A, Kaplan MH, Zhang Y, et al. 2014. STAT5 programs a distinct subset of GM-CSF-producing Thelper cells that is essential for autoimmune neuroinflammation. Cell Res 24: 1387-1402.

Smith PA, Heijmans N, Ouwerling B, Breij EC, Evans N, van Noort JM, Plomp AC, Delarasse C, Hart B, Pham-Dinh D, et al. 2005. Native myelin oligodendrocyte glycoprotein promotes severe chronic neurological disease and demyelination in Biozzi ABH mice. Eur J Immunol 35: 13111319.

Sobel RA, van der Veen RC, Lees MB. 1986. The immunopathology of chronic experimental allergic encephalomyelitis induced in rabbits with bovine proteolipid protein J Immunol 136: 157-163.

Soderstrom M. 2001. Optic neuritis and multiple sclerosis. Acta Ophthalmol Scand 79: 223-227.

Song ZY, Yamasaki R, Kawano Y, Sato S, Masaki K, Yoshimura S, Matsuse D, Murai H, Matsushita T, Kira J. 2014 Peripheral blood $\mathrm{T}$ cell dynamics predict relapse in multiple sclerosis patients on fingolimod. PLOS ONE 10: e0124923.

Sorensen PS, Lisby S, Grove R, Derosier F, Shackelford S, Havrdova E, Drulovic J, Filippi M. 2014. Safety and efficacy of ofatumumab in relapsing-remitting multiple sclerosis: A phase 2 study. Neurology 82: 573-581.

Sospedra M, Martin R. 2005. Immunology of multiple sclerosis. Annu Rev Immunol 23: 683-747.

Stephens LA, Malpass KH, Anderton SM. 2009. Curing CNS autoimmune disease with myelin-reactive Foxp $3^{+}$Treg. Eur J Immunol 39: 1108-1117.

Stromnes IM, Cerretti LM, Liggitt D, Harris RA, Goverman JM. 2008. Differential regulation of central nervous sys- tem autoimmunity by $\mathrm{T}_{\mathrm{H}} 1$ and $\mathrm{T}_{\mathrm{H}} 17$ cells. Nat Med 14: 337-342.

Sun J, Link H, Olsson T, Xiao BG, Andersson G, Ekre HP, Linington C, Diener P. 1991a. T and B cell responses to myelin-oligodendrocyte glycoprotein in multiple sclerosis. J Immunol 146: 1490-1495.

Sun JB, Olsson T, Wang WZ, Xiao BG, Kostulas V, Fredrikson S, Ekre HP, Link H. 1991b. Autoreactive T and B cells responding to myelin proteolipid protein in multiple sclerosis and controls. Eur J Immunol 21: 1461-1468.

Sun D, Whitaker JN, Huang Z, Liu D, Coleclough C, Wekerle $\mathrm{H}$, Raine CS. 2001. Myelin antigen-specific $\mathrm{CD} 8^{+} \mathrm{T}$ cells are encephalitogenic and produce severe disease in C57BL/6 mice. J Immunol 166: 7579-7587.

Teitelbaum D, Meshorer A, Hirshfeld T, Arnon R, Sela M. 1971. Suppression of experimental allergic encephalomyelitis by a synthetic polypeptide. Eur J Immunol 1: 242248.

Teitelbaum D, Webb C, Bree M, Meshorer A, Arnon R, Sela M. 1974. Suppression of experimental allergic encephalomyelitis in Rhesus monkeys by a synthetic basic copolymer. Clin Immunol Immunopathol 3: 256-262.

Tennakoon DK, Mehta RS, Ortega SB, Bhoj V, Racke MK, Karandikar NJ. 2006. Therapeutic induction of regulatory, cytotoxic $\mathrm{CD}^{+} \mathrm{T}$ cells in multiple sclerosis. J Immunol 176: 7119-7129.

Trinschek B, Luessi F, Haas J, Wildemann B, Zipp F, Wiendl H, Becker C, Jonuleit H. 2013. Kinetics of IL-6 production defines $\mathrm{T}$ effector cell responsiveness to regulatory $\mathrm{T}$ cells in multiple sclerosis. PLoS ONE 8: e77634.

Tuohy VK, Lu ZJ, Sobel RA, Laursen RA, Lees MB. 1988. A synthetic peptide from myelin proteolipid protein induces experimental allergic encephalomyelitis. J Immunol 141: 1126-1130

Tuohy VK, Lu Z, Sobel RA, Laursen RA, Lees MB. 1989. Identification of an encephalitogenic determinant of myelin proteolipid protein for SJL mice. J Immunol 142: 1523-1527.

Veldhoen M, Hocking RJ, Atkins CJ, Locksley RM, Stockinger B. 2006. TGF $\beta$ in the context of an inflammatory cytokine milieu supports de novo differentiation of IL-17-producing T cells. Immunity 24: 179-189.

Venken K, Hellings N, Hensen K, Rummens JL, Medaer R, D’Hooghe M B, Dubois B, Raus J, Stinissen P. 2006. Secondary progressive in contrast to relapsing-remitting multiple sclerosis patients show a normal $\mathrm{CD} 4^{+} \mathrm{CD} 25^{+}$ regulatory T-cell function and FOXP3 expression. J Neurosci Res 83: 1432-1446.

Viglietta V, Baecher-Allan C, Weiner HL, Hafler DA. 2004. Loss of functional suppression by $\mathrm{CD} 4^{+} \mathrm{CD} 25^{+}$regulatory $\mathrm{T}$ cells in patients with multiple sclerosis. J Exp Med 199: 971-979.

Waksman BH, Porter H, Lees MD, Adams RD, Folch J. 1954. A study of the chemical nature of components of bovine white matter effective in producing allergic encephalomyelitis in the rabbit. J Exp Med 100: 451-471.

Waldner H, Whitters MJ, Sobel RA, Collins M, Kuchroo VK. 2000. Fulminant spontaneous autoimmunity of the central nervous system in mice transgenic for the myelin proteolipid protein-specific T cell receptor. Proc Natl Acad Sci 97: 3412-3417. 
Waldner H, Collins M, Kuchroo VK. 2004. Activation of antigen-presenting cells by microbial products breaks self-tolerance and induces autoimmune disease. J Clin Invest 113: 990-997.

Walker LS, Abbas AK. 2002. The enemy within: Keeping self-reactive $\mathrm{T}$ cells at bay in the periphery. Nat Rev Immunol 2: 11-19.

Wang RX, Yu CR, Dambuza IM, Mahdi RM, Dolinska MB Sergeev YV, Wingfield PT, Kim SH, Egwuagu CE. 2014a. Interleukin-35 induces regulatory B cells that suppress autoimmune disease. Nat Med 20: 633-641.

Wang Y, Godec J, Ben-Aissa K, Cui K, Zhao K, Pucsek AB, Lee YK, Weaver CT, Yagi R, Lazarevic V. 2014b. The transcription factors T-bet and Runx are required for the ontogeny of pathogenic interferon- $\gamma$-producing $T$ helper 17 cells. Immunity 40: 355-366.

Webb M, Tham CS, Lin FF, Lariosa-Willingham K, Yu N, Hale J, Mandala S, Chun J, Rao TS. 2004. Sphingosine 1phosphate receptor agonists attenuate relapsing-remitting experimental autoimmune encephalitis in SJL mice. J Neuroimmunol 153: 108-121.

Weber MS, Prod'homme T, Patarroyo JC, Molnarfi N, Karnezis T, Lehmann-Horn K, Danilenko DM, Eastham-Anderson J, Slavin AJ, Linington C, et al. 2010. Bcell activation influences T-cell polarization and outcome of anti-CD20 B-cell depletion in central nervous system autoimmunity. Ann Neurol 68: 369-383.

Whitham RH, Bourdette DN, Hashim GA, Herndon RM, Ilg RC, Vandenbark AA, Offner H. 1991. Lymphocytes from SJL/J mice immunized with spinal cord respond selectively to a peptide of proteolipid protein and transfer relapsing demyelinating experimental autoimmune encephalomyelitis. J Immunol 146: 101-107.

Xiao BG, Linington C, Link H. 1991. Antibodies to myelinoligodendrocyte glycoprotein in cerebrospinal fluid from patients with multiple sclerosis and controls. J Neuroimmunol 31: 91-96.

Yang XO, Panopoulos AD, Nurieva R, Chang SH, Wang D, Watowich SS, Dong C. 2007. STAT3 regulates cytokinemediated generation of inflammatory helper T cells. J Biol Chem 282: 9358-9363.

Yang Y, Weiner J, Liu Y, Smith AJ, Huss DJ, Winger R, Peng H, Cravens PD, Racke MK, Lovett-Racke AE. 2009. T-bet is essential for encephalitogenicity of both Th1 and Th17 cells. J Exp Med 206: 1549-1564.

Yednock TA, Cannon C, Fritz LC, Sanchez-Madrid F, Steinman L, Karin N. 1992. Prevention of experimental autoimmune encephalomyelitis by antibodies against $\alpha 4 \beta 1$ integrin. Nature 356: 63-66.

Zamvil S, Nelson P, Trotter J, Mitchell D, Knobler R, Fritz R, Steinman L. 1985a. T-cell clones specific for myelin basic protein induce chronic relapsing paralysis and demyelination. Nature 317: 355-358.

Zamvil SS, Nelson PA, Mitchell DJ, Knobler RL, Fritz RB, Steinman L. 1985b. Encephalitogenic T cell clones specific for myelin basic protein. An unusual bias in antigen recognition. J Exp Med 162: 2107-2124.

Zamvil SS, Mitchell DJ, Moore AC, Kitamura K, Steinman L, Rothbard JB. 1986. T-cell epitope of the autoantigen myelin basic protein that induces encephalomyelitis. Nature 324: $258-260$

Zang YC, Li S, Rivera VM, Hong J, Robinson RR, Breitbach WT, Killian J, Zhang JZ. 2004. Increased CD8 ${ }^{+}$cytotoxic $\mathrm{T}$ cell responses to myelin basic protein in multiple sclerosis. J Immunol 172: 5120-5127.

Zelenika D, Grima B, Pessac B. 1993. A new family of transcripts of the myelin basic protein gene: Expression in brain and in immune system. J Neurochem 60: 15741577.

Zhang J, Markovic-Plese S, Lacet B, Raus J, Weiner HL, Hafler DA. 1994. Increased frequency of interleukin 2responsive $\mathrm{T}$ cells specific for myelin basic protein and proteolipid protein in peripheral blood and cerebrospinal fluid of patients with multiple sclerosis. J Exp Med 179: 973-984.

Zhang X, Koldzic DN, Izikson L, Reddy J, Nazareno RF, Sakaguchi S, Kuchroo VK, Weiner HL. 2004. IL-10 is involved in the suppression of experimental autoimmune encephalomyelitis by $\mathrm{CD} 25^{+} \mathrm{CD} 4^{+}$regulatory T cells. Int Immunol 16: 249-256.

Zhou L, Lopes JE, Chong MM, Ivanov II, Min R, Victora GD, Shen Y, Du J, Rubtsov YP, Rudensky AY, et al. 2008. TGF$\beta$-induced Foxp3 inhibits $\mathrm{T}_{\mathrm{H}} 17$ cell differentiation by antagonizing ROR $\gamma \mathrm{t}$ function. Nature 453: 236-240.

Ziegler SF. 2006. FOXP3: Of mice and men. Annu Rev Immunol 24: 209-226. 


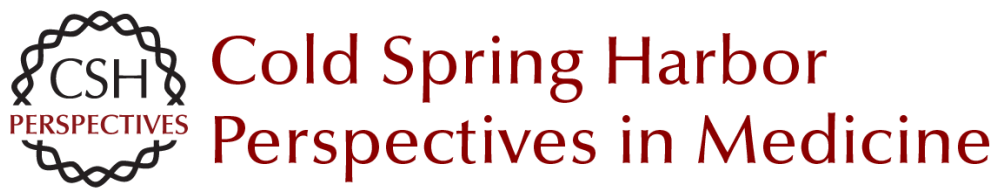

\section{Experimental Autoimmune Encephalomyelitis (EAE) as Animal Models of Multiple Sclerosis (MS)}

Simon Glatigny and Estelle Bettelli

Cold Spring Harb Perspect Med 2018; doi: 10.1101/cshperspect.a028977 originally published online January 8, 2018

\begin{tabular}{|c|c|}
\hline Subject Collection Multiple Sclerosis & \\
\hline $\begin{array}{l}\text { Multiple Sclerosis Pathology } \\
\text { Hans Lassmann }\end{array}$ & $\begin{array}{l}\text { Natalizumab: Perspectives from the Bench to } \\
\text { Bedside } \\
\text { Afsaneh Shirani and Olaf Stüve }\end{array}$ \\
\hline $\begin{array}{l}\text { Regulatory T Cells: From Discovery to } \\
\text { Autoimmunity } \\
\text { Alexandra Kitz, Emily Singer and David Hafler }\end{array}$ & $\begin{array}{l}\text { Daclizumab Therapy for Multiple Sclerosis } \\
\text { Bibiana Bielekova }\end{array}$ \\
\hline $\begin{array}{l}\text { The Multiple Roles of B Cells in Multiple Sclerosis } \\
\text { and Their Implications in Multiple Sclerosis } \\
\text { Therapies } \\
\text { Rui Li and Amit Bar-Or }\end{array}$ & $\begin{array}{l}\text { Lifestyle and Environmental Factors in Multiple } \\
\text { Sclerosis } \\
\text { Lars Alfredsson and Tomas Olsson }\end{array}$ \\
\hline $\begin{array}{l}\text { Autologous Hematopoietic Stem Cell } \\
\text { Transplantation in the Treatment of Multiple } \\
\text { Sclerosis } \\
\text { Carolina A. Rush, Harold L. Atkins and Mark S. } \\
\text { Freedman }\end{array}$ & $\begin{array}{l}\text { Biomarkers in Multiple Sclerosis } \\
\text { Anu Paul, Manuel Comabella and Roopali Gandhi }\end{array}$ \\
\hline $\begin{array}{l}\text { B-Cell Therapies in Multiple Sclerosis } \\
\text { Joseph J. Sabatino, Jr., Scott S. Zamvil and } \\
\text { Stephen L. Hauser }\end{array}$ & $\begin{array}{l}\text { The Evolving Mechanisms of Action of Glatiramer } \\
\text { Acetate } \\
\text { Thomas Prod'homme and Scott S. Zamvil }\end{array}$ \\
\hline $\begin{array}{l}\text { Oral Therapies for Multiple Sclerosis } \\
\text { Simon Faissner and Ralf Gold }\end{array}$ & $\begin{array}{l}\text { Regulation of Astrocyte Functions in Multiple } \\
\text { Sclerosis } \\
\text { Michael A. Wheeler and Francisco J. Quintana }\end{array}$ \\
\hline $\begin{array}{l}\text { Interferon } \beta \text { for Multiple Sclerosis } \\
\text { Dejan Jakimovski, Channa Kolb, Murali } \\
\text { Ramanathan, et al. }\end{array}$ & $\begin{array}{l}\text { Experimental Autoimmune Encephalomyelitis } \\
\text { (EAE) as Animal Models of Multiple Sclerosis (MS) } \\
\text { Simon Glatigny and Estelle Bettelli }\end{array}$ \\
\hline $\begin{array}{l}\text { Alemtuzumab as Treatment for Multiple Sclerosis } \\
\text { Serafeim Katsavos and Alasdair Coles }\end{array}$ & $\begin{array}{l}\text { Neurodegeneration in Progressive Multiple } \\
\text { Sclerosis } \\
\text { Graham Campbell and Don Mahad }\end{array}$ \\
\hline
\end{tabular}

For additional articles in this collection, see http://perspectivesinmedicine.cshlp.org/cgi/collection/ 